\title{
Nutraceautical Wild Fruit of India-Capparis decidua (Forssek.) Edgew. Caper Tree/Karira
}

\author{
Ahuja, S. $C^{1^{*}}$, Siddharth Ahuja ${ }^{2}$, Uma Ahuja ${ }^{3}$
}

${ }^{1}$ Retired Plant Pathologist, Rice Research Station, V \& PO Kaul, District Kaithal, 136021, India

${ }^{2}$ Assistant Professor, Department of Pharmacology, Sahid Hasan Khan Mewati Medical College Nalharh, Mewat, Haryana, India

${ }^{3}$ Retired Professor, Genetics and Plant Breeding, College of Agriculture, CCS Haryana Agricultural University, V\&PO Kaul, District Kaithal, Haryana-136021, India

*Corresponding author: Ahuja, S. C

Abstract

Capparis decidua (Forssk.) Edgew. (CD) commonly known as Caper tree/ Karira is a small much, branched shrub. It is an important species of desert and arid regions to the tropical and subtropical regions of India, Arabia, Pakistan and Africa including Egypt. It provides vegetative cover in dry, hot, sandy desert areas, improves soil, prevents soil erosion and promotes biodiversity. It is a source of food, fodder, fuel wood, timber, medicine and plays an important role in the rural economy of arid regions. Its hard, heavy and termite resistant timber is known as "Sandal Wood" of the desert India. Fruits are eaten raw, unripe fruits and flowers are used pickled used as vegetable, dried fruits are turned into a delicacy in Rajasthan. In many parts of India, Africa and East Asia fruit serves as source of survival and food during famines. Records of CD appear in Vedas, Ayurvedic treatises as Charaka and Sushrut Samhita and classical Sansktit texts of Panini, Brihat Samhita of Varah Mihir, Upavana Vinoda and Vishvavallabha. The plant has been used as anti-inflammatory, anti asthmatic, analgesic, cardio protective anathematic, purgative, ant-helmintic, hepato protective, astringent, neutraceutical and antimicrobial in Ayurveda, Siddha, Unani systems of medicine since 2000 years. Plant seems to be a future green source of cosmetic, bio-inhibitor of metallic corrosion, nano-technology and bio diesel. The review presents the history, folklore, distribution, use as food, fodder, medicine in folk, animal and human health; it's pharmaceutical and therapeutic, cultural, ecological and miscellaneous uses and nutritional and nutraceutical value.

Keywords: History, names, uses, pharmacological testings, folklore.

Copyright (C) 2020 The Author(s): This is an open-access article distributed under the terms of the Creative Commons Attribution 4.0 International License (CC BY-NC 4.0) which permits unrestricted use, distribution, and reproduction in any medium for non-commercial use provided the original author and source are credited.

\section{INTRODUCTION}

Capparis decidua(Forssk.) Edgew. (CD) commonly known as Caper tree/ Karira/Kair/Ker is a multipurpose perennial woody plant, of caper family (Capparaceae). The Genus Capparis owes its name to the Arabic word 'kabar' for capers, through Greek, kapparis, and species name is derived from deciduus - $a-$ $u m$, meaning not persisting, falling-off or deciduous. Out of 45 species, 26 occur in India [1]. It is a small much-branched shrub that provides food, fodder, fuel wood, timber, medicine and plays an important role in the rural economy of arid regions. Plant is used as diet supplement for goat, sheep, camel and other animals during scarcity period of grass. Its timber is hard, heavy and termite resistant and has earned epithet "Sandal Wood" of the desert in India.

\section{Habit and Distribution}

$\mathrm{CD}$ is a shrub of dense tufts, but can also grow as a small tree (4-5 m high). Branches and twigs are glossy dark green and bark turns whitish grey with age. Small, light brown spines occur in pairs on the branches at each node. Leaves are very minute ( $2 \mathrm{~mm}$ long) and emerge on young shoots, have very short life and plant looks leafless most of the time. Flowers are pink, red-veined; emerge in small groups along the leafless shoots at the axils of the spines. Fruit is small dull red berry, many-seeded ovoid and $1-2 \mathrm{~cm}$ in diameter, becomes blackish when dry. The seeds are $2-5 \mathrm{~mm}$ diameter, and are embedded in the pulp. It produces leaves, flowers and fruits twice or thrice in a year. Flowering and fruiting takes place in February-March and July-August. Summer months are peak flowering time and maximum mature fruits are available just before onset of monsoon. Flowering 1-2 months earlier to the onset of rainy season ensures availability of seeds for germination at the time of rainfall. Fruit yield varies between $2-20 \mathrm{~kg}$ per plant depending on age, genetic potential, and flowering season. 
Harvesting fruits at right time and right stage of maturity is very important. This being 7-10 days after fruit set with 5-8 mm diameter during March-April [2]. The cured fruits can be prepared into vegetable curry, pickle or sun dried for use in the off season. Properly sun dried immature fruits of kair fetch in the urban retail market Rs. 800-1200 kg-1 depending upon the size. The smallest sized fruits fetch the highest price [2].

CD coppices well and readily produce root suckers. This adaptation ensures continuity of the species. The plant can afford this behaviour because of deep and extensive root system (up to four meters) and its ability to draw moisture from deeper soil layers [3, 4, $5]$. CD is mainly propagated by seeds and root suckers under natural conditions $[6,7]$.

\section{Sanskrit text Namarupajnanam} (Characterization of Medicinal Plants) describes Karira as a plant of arid zone marubhurha, having small leaves on new shoots, the old branches staying leafless apatra, gudhapatra. Leaves and root are pungent and bitter (katutiktaka, tiksnasar). Branches are nodular (granthila) with sharp spines (krakara, tiksnakantaka). Round, soft fruits (mrduphala) and also flowers are used as vegetable (sakpuspa) [8].

It is a hardy species and grows preferably in dry, arid and exposed habitats like wastelands, ditches, drying ponds, cultivated lands, road sides and surrounding plains of hills on very shallow and soils affected by saline irrigation water, and in stabilized sand dunes [9]. It provides vegetative cover in dry, hot, sandy desert areas, improves soil, prevents soil erosion and promotes biodiversity $[10,11]$. It is common in rangelands, barren fields, farm boundaries and wasteland in Rajasthan due to its excellent adaptations to survive under prolonged drought condition. Although it is well suited to areas with low rainfall $(150 \mathrm{~mm})$, kair can survive in areas with rainfall as high as $600 \mathrm{~mm}$ and temperatures from $16-50^{\circ} \mathrm{C}$ [3]. It grows in association with Acacia senegal (L.) Willd., Calotropis procera (Ait.) R. Br., Grewia tenax (Forssk.) Fiori , Maytenus emarginata (Willd.) Ding-Hou, Ziziphus nummularia (Burm.f.) Wt. et Arn., Salvadora oleoides Decne, Prosopis cineraria (L.) Druce.
$\mathrm{CD}$ is an important shrub species of desert and arid regions to the tropical and subtropical regions of India, Africa, Arabia, Pakistan and Egypt. It is distributed in tropical and subtropical regions of Chad, Egypt, Ethiopia, India, Arabia, Pakistan, Iran, Jordan, Mauritania, Niger, Nigeria, Senegal, Somalia, South Africa, Sudan and Egypt. In India it occurs in Gujarat, western Rajasthan, Uttar Pradesh, Madhya Pradesh, Haryana, Punjab and parts of Tamil Nadu, Karnataka and Andhra Pradesh [12].

\section{History}

\section{Written Records}

Records of CD as Karira appear in Yayurveda (1000 BC) and in Kāthaka samhitā (1200- 800 BCE) [13, $14]$. It finds mention as a nutraceutical fruit in ayurvedic treatises as Charka Samhita (700 BC), Sushrut Samhita (400 BC) and Madanpal Niganhtu (1100AD). References on CD occur in classical Sanskrit texts of Panini (500BC) and Brihat Samhita of Varah Mihir (505-587AD); Upavana Vinoda (1300AD), Vishvavallabh (1577AD) and Matsyapurana (earlier to 700AD). It is also recorded in epic poems of Ramayana (200 AD); and Mahabharata (400 AD) $[15,16]$. CD also appears in Sanskrit text of Kadambari of Banabhatta \{a courtier of King Harsha Vardhana who reigned from c. 606- 647 AD in North India first from Sthanishvara Thanesvar)\}, and later Kanauj and in Vakapati's historical poem in Prakrit Gaudovah or Gaudavadha, composed in 1887.

\section{Names and Synonymy}

Its vernacular and common names are prevalent in 17 Indian, 5 Asian, 5 African and 6 European languages, dialects / countries (Table-1).

$\mathrm{CD}$ is referred as Karira in Yayurveda, Maitrayan̄̄ Samihitā, Taittirīya Brāhmaṇa (300-400 BCE), Taittiriya Samihitā, Śatapatha Brāhmaṇa (800 to 600 BCE), and Kāthaka Samhitā. Amarkosha (500-800 AD) lists three names (Karir, Krakar and Granthila) for it. While Namarupajnanam as mentioned earlier, provides nine names based on the plant characters [8]. CD is known by 29 names in Sanskrit, Tamil (25), Hindi (15), Telugu (3) and Urdu (4) (Table-1). Prevalence of large number of names in Indian languages/ dialects indicates its Indian nativity. 
Table-1: Names of Capparis decidua in various Indian and Foreign Languages

Sanskrit: Karira*, Apatra, Chakrak, Granthila, Gudhpatra, Kantaki, Karaka, Kataphala, Katutiktaka, Krakara, Krakaripatra, Krakatha, Krishashakha, Marubhuruh, Mrduphala, Nigudhpatra, Nispatrak, Nispatrika, Sakpushpa, Shatakunta, Shonapushpa, Suphal, Tikshnakantaka, Teekshnakantaki, Teekshnasar, Ushnasundara,Vidahika, Vishvakpatra, maruruhu, mar vidahika, ubhuruha $31 *$ bold =names in [8]

Bangla: Karil;

Bihar: Kari;

Gujarati: Kerdo, Kair, Kera, Kerda,ker 5;

Haryana: Tind (F), Kair;

Hindi: Karel, Karila, Kair, Kabra, Kachra, Karer, Karir, Karira, Karia, Kario, Karil, Karu, Ker, Kerro, Kurel, Kurrel, Pinju, lete, Satari,Teent, Tent, Tenti, Babula ki tenti 22;

Kannad: Chippuri, Cippuri, Kaareela, Kareera, Karira, Kariuppi-gidda, Keraa, Kiruli, Niovate-gidda, Nispatley -gida, Nispatige, Shipri 11;

Kokani: Kiral;

Kutchi: Davra;

Malayam: Karimulli, Karimullu;

Marathi: Nepati, Karil, Ker, Nevati;

Odia: Kirir, Krakara;

Punjabi: Bander, Barar, Barari, Bassar, Bauri, Ber, Kabarra, Kabra, Kakri, Kanda, Kaur, Keri, Kiari, Taker; Delha (F), Karia, Karil, Karin, Karis, Kerin, Kirra, Pinju, Tenti; Rajasthan:, Ke, Kair, Dhalu, Kareal Kerro, Taint,Teent 8;

Sindhi: Dorakiram, Kirab, Kiral, Kirid, Kirrur Kirer 7;

Tamil: Cattiputpam, cattiracoputpam, cinaikaravi, cinaikaravicceti, ciracukkilam, cirakakoli, cirakatantai, cirakkoli, ciratci, cutakkini, Kariram, kelal, kentikam, kuraram, Karyal, Kulaladondai, kulalatontai, marupurukam, palaccaka, sengam, senkam, sirakkali,vayacca, vayaccam, venu 25;

Telegu: Enugadanta, Kariramu, Mumudatu 3;

Urdu: Titali, karir, kachia phal, kabar, pichu, $\mathbf{5}$

Afganistan:Pusto :Kira, Kreeta (Seraki); Pakistan: Gunger; Balochistan: Karar, North Balochistan: Khawarg, Ormara Balochiatan: Krap, Gawadar Balochistan: Kder; Punjab: Karri, dela; Sindh: Kareer, Kirrer; Chinese: Wu ye shan gan; Tibetian: Karira, Karira, rgyasnalu, rgya sneu (p\& d), uboka (d), upotaka (p), upota kila Kabra; Persian: Bergesodab, Kebir, Kurake, Sodab Kabar, Kebir, Kurak

Africa: Swartsorm, Babejaanarm; Alegeria: Toundoub, Habriga (Arabic), Koussoms (Berber); Arabic: Hanbag, Kiabara, Margh, Sodab, Tundub, Murkheit, Kursan, Khiran, Khirar,Habriga, Sarwab, Chad central: Arabic Tountoub; Egypt: Bischarin tribe :Hanboaq, Sarwab, Khushmaun tribe: Tundhub, Balaha Tundhub (F); Ethiopia : Injet, Maluza, Yomonoxe; Hebrew: Retama caper, Tsalaf ratami; Somali: Meringa; Syria: Kabar;

Europe: English: Caper, Desert broom; French: Caprier sans feuilles, caprier; Malta: Caper plant, capparo, cappara; Morocco: Ignin; Portuguese: Alcaparra; Russian: Kapersovyi kust, Spanish: Alcaparra, Alcaparro; Turkish: Kabarish

\section{Origin}

Archeological evidences in the shape of wood charcoal reveal that CD (Capparis aphylla), Manikarna hexandra and Prosopis spicigera were grown in Punjab since pre historic periods (Pre-Harappa phase, 2300-2000BC) [19, 20]. In North-western drier plains of India, 26 wild relatives of Capparis including those of $\mathrm{CD}$ have been recorded particularly in sand dunes habitat and rocky areas [21]. The archaeological evidences, historical records, philological evidence in the shape of innumerable names (Table-1) and frequent occurrences of $\mathrm{CD}$ in folklore and literature of Indian languages indicate and corroborate its Indian nativity.

\section{Uses}

Food

$\mathrm{CD}$ is nutrient rich indigenous plant whose flowers, flower buds and fruits are used as vegetable, in pickle making and as food [4]. Since ancient times, the people of arid and semi-arid regions of Afghanistan, Pakistan and North Western India have used caper berry pickle. Many ethnic groups of Rajasthan, Uttar Pradesh, Haryana, Madhya Pradesh, Gujarat and Maharashtra use fresh and blanched fruit as vegetable because of perceived belief of its neutraceutical value [22-24].
Fruits are cooked as vegetables alone and along with those of Prosopis cineraria and seeds of Acacia senegal and dried fruit form an important ingredient of the famous "Panchkoot'" mixtures of dry vegetables of Rajasthan. The dehydrated fruits are extensively used as off-season vegetable and are highly priced $[5,25]$. The raw fruits serve as food for survival in wilderness and used during the time of food shortages in India and Sudan $[4,26]$.

In Egypt, Khushmaun people of Mazza tribe cook and eat the fruit without seeds because these are considered to induce vomiting and Bischarin of Beja tribe eats ripe fruits for their nutritional value [27].

$\mathrm{CD}$ is also used in preparation of mouth freshener [28]. Folks in Rajasthan use dried and roasted seeds as a diet [29]. Caper sauce is a popular accompaniment to baked fish in the west, a practice which continued in colonial India [30]. People of Rajasthan and Haryana use its flower buds for food flavoring and fruit extract in the food processing industry as a flavor agent [29] and root ash as a source of salt [31]. In India, the stems are used to stupefy fish. The fruits and flower-buds are commonly pickled and used as a condiment [32]. 


\section{Fodder}

The cattle relish perennial grasses from August to November, while in summer season, green shoots of Calligonum polygonoides and CD form browse of cattle which during other seasons are not liked by the animal [33]. The young twigs serve as a fodder for camels and goats. It is use as food of camel since ancient times. In Rajputana and Sudan, the plant is fed to animals as fodder [34, 35]. Its green and dried leaves are used as diet supplement for goat, sheep, camel and other animals during scarcity period of grass [36].

In Banaskantha, Gujarat, folks traditionally mix CD fruits with fodder to increase milk production in animal. Flavonoids, present in Capparis plants, possess oestrogen binding properties [37] and act as a galactagogue to increase milk production in animal.

The proximate composition of shoot shows: dry matter content $(50.8 \%)$, digestible dry matter $(49.7 \%)$, crude protein $(12.1 \%$; true protein, $9.5 \%$; non protein nitrogen, $3.4 \%)$, crude fiber $(29.6 \%)$, NDF (60.6\%) and $\mathrm{ADF}(50.0 \%)$. The minerals constituents included $\mathrm{Ca}$, $\mathrm{Na}, \mathrm{K}, \mathrm{Zn}, \mathrm{Mn}, \mathrm{Fe}, \mathrm{Cu}$, and $\mathrm{Ni}$ [38]. CD shoots being rich in protein content and having adequate amount of minerals are useful as fodder [39]. Livestock animals require protein for maintaining growth and reproduction, metabolism. Its deficiency leads to reduced appetite, low feed intake resulting in poor growth and development [40]. Gull et al. [38] maintains that Ca content of CD is lesser than other fodders but it can fulfill the livestock's requirement during periods of non-availability of any other fodder.

\section{Fuel Wood and Timber}

Its timber is hard, heavy and termite resistant. The wood strength and durability is suitable for making water pipes, water troughs, small beams, rafts, knees of boats, tool handles, cart wheels, axles and combs. It also serves as material for making huts and fences. Wood being strong and durable is also used in making of agricultural implements and foundation around well [28, 41]. CD wood is used in carving and cobblers take advantage of its high quality imparted by less xylem fibres [35]. Mehars of Gujarat use stem for making lower portion (phool) of churning rod [42]. In Egypt the dried plant serves as fuel and wood is used in preparation of the basuur (camel saddle). Wood finds use as firewood and for preparing charcoal. CD wood has good fuel wood characteristics like calorific value, density, volatile matter and fuel wood index [43].

\section{Use in Agriculture}

In cultivating land this plant is grown to form hedges for protection. Its prickly branches are used to make 'Kanti' to protect emerging seedlings of groundnut [44]. In Gujarat farmers spray boiled infusion of tender CD leaves to control aphids and sucking pests in crops [45]. As mentioned earier, Ker wood resists the termite attack, therefore, thinner branches are used for fencing the field and mulching.

\section{Medicine}

Ayurveda

$\mathrm{CD}$ finds reference in a number of Ayurvedic treatises and dictionaries. It is classified both as ahara (food, saka/vegetable or phala/fruit) and as a medicine. Mādhava Dravyaguṇa considers it as a food as well as a medicine. Așțāmga Hṛdaya and Madanapāla Nighaṇṭu categorised it as a vegetable (Saka) while Kaidav Nighantu and Amarkosha of Amar Singha treated under it herbal medicine. Caraka and Susrut Samhitas described it in phalavarga (Fruit section) and tikta skanda (Pungent/bitter Canto). Abhidhānaratnamāla and Matsya Puran classified in kașāya skandha (Caustic Canto) while Bhāvaprakāśa Nighaṇțu dealt it in vațādi varga (Wind section) [46].

Fruits and flowers when taken internally subdue vayu (wind) and pitta (heat/energy/bile) and increase urine and stool [47]. Its fruits are madhur (sweet in taste), kasaya (caustic), sita (cool) and pacifiers of pitta-kapha [48]. Charak Samhita recommends regular use of leaves in diet for invigoration of eyesight. Its vegetable is useful in fevers, cough, hiccup and chronic skin and urinary diseases. In Kausika sutra the root and stem are prescribed as an anthelimintic [14]

Ayurvedic experts regarded the plant as acrid, laxative, counter-irritant and stimulant and often prescribed in heart diseases, colic pains, scurvy and phthisis [34]. They used the plant in flatulence, anorexia, respiratory disorders, skin diseases, in general weakness, as anthelmintic and as diuretic $[49,50]$. The infusion of plant is used externally for eruptions, boils, joint diseases and internally in cough and as an antidote of poisoning. Juice of fresh plant is kills worms in ear. It is a good substitute of senega [34, 51].

Classical uses of plant include cure of bleeding and dry piles, oedema, vatrakta (rashes, anaesthetic patches, and pain in joints), improving eyesight, and constipation [52]. The fruits are astringent and used as laxative in chronic constipation and are also useful in biliousness, cardiac troubles, halitosis and vitiated conditions of Pitta [52]. Fruits destroy foul breath, biliousness, urinary purulent discharge and help cure of cardiac troubles [28].

Roots are considered to be sudorific, thermogenic, expectorant, carminative, digestive, stimulant, antibacterial, aphrodisiac, anodyne, anthelmintic and are useful in arthritis, dyspepsia, constipation, lumbago, odontalgia, amenorrhoea and dysmenorrhoea [53]. while root bark is astringent, acrid, diaphoretic, alexeteric, analgesic, laxative, anthelminthic and useful for cough, asthma, ulcers, boils, vomiting, piles, inflammations and cleaning vagina [5]. 
Root bark powder or infusion is useful in gout, rheumatism, cough, dropsy, palsy, asthma, intestinal worms and intermittent fever. The powder is applied externally on malignant ulcer [34, 54].

$\mathrm{CD}$ is constituent of Ayurvedic formulations Kottamchukkadi Choornam (KC), and MAK5 (Maharishi Amrit Kalash). $\mathrm{KC}$ is applied externally for relief of pain in joints, arthritis and swelling and acts by balancing Vata and Kapha. MAK5 contains many herbs rich in antioxidants and reduces chemotherapic toxicity among women with breast cancer [55].

\section{Siddha System}

Siddha Bhesja Manimaalana recommends the use of tender stem, dried fruits with fatty curd in bleeding piles, alkali of fruit in dry piles, and powdered fruit in oedma, inflammations and skin infections due to vitiated blood. Oil extracted from fresh stem is rubbed on affected parts. The paste of root bark is applied to malignant tumours, boils, rheumatic swellings and gout. Infusion of root is taken internally as anti-toxic agent [56]. Vatebhkesari Ras containing CD tender stem is used in pneumonia, unconsciousness, cough, breathlessness, disorders of bodily humors, hiccup, flatulence, head pain, fever of pitta and gonorrhea and as an aphrodiasiac.

\section{Unani/Greek and Greco- Arab System}

In Unani system of medicine, Karīra is used as a tonic, aphrodisiac, carminative, emmenagogue, alexipharmic, appetizer, rheumatism, hiccough, lumbago, asthma and cough [57] Shoots of CD and Peganum harmala are used as anti-fertility drug; ground stem and leaves in alvelaris and pyorrhea; root bark as antihelminthic and purgative; wood coal in muscular injuries. Leaves act as appetizer, help in cardiac troubles and fruits in biliousness [57, 58, 59].

It is a constituent in a number of Unani formulations as Hab Hamal (pills for conception), Hab Mumsik Ambari (aphrodisiac and retentive pills), Hab Mumsik Tilai (sexual debility and impotency), Kushta Tamba Safaid (fine powder of copper white), Ma'jun(confection) Falak Sayr, Ma'jun Kalan, Ma'jun Masikal-Boul (for strengthening of the urinary bladder, incontinence of urine, diabetes, weakness of the liver, enuresis), Ma'jun Maurawweh ul-Arwah (premature ejaculation, erectile dysfunction), Ma'jun Muqawwi Wa Mumsik (impotency), Ma'jun Suranjan (rheumatism, gout, sciatica, all types of aches), Roghan Aqrab (oil scorpion) - a pain killer, Safuf Qinnab (powder Cannabis), Zimad Bars compounds (medicine )[60].

\section{Folk Medicine}

$\mathrm{CD}$ is widely used in folk medicine in India, Pakistan, Sudan, Algeria, Egypt, Libya, Morocco and
Tunisia. External or internal use of the plant and its parts help in checking a number of diseases.

The fruit is used for asthma, constipation, gastritis, and tuberculosis; flower for cough, jaundice and typhoid; stem for cough, eczema, cuts, injury, fracture, eye problems, gastritis and excessive mensuration; bark for arthritis and boils; root for body pain and skin problems; and leaves for dental problems, eczema and tuberculosis [61]. People take Ker mixed with sugar candy to stop blood from nose and in stool, dropsy; root oil for pain in ribs; root ash with ghee for joint pain; dried shoots with black pepper for spleen pain, powdered bark for constipation; wood ash for cough; wood ash mixed with ghee for relief from joint pains. While tying a tablet prepared by ground soft growing points and soft leaves is recommended for fever; bafara (steam) and application of leaf juice controls night blindness [62]. People consider the plant to possess hypoglycemic effect in diabetes and use green berries and flower buds as vegetable and curry to reduce blood sugar [34, 63]. The vegetable prepared from fruits in ghee is believed to be good for eyes [49].

In Bikaner, Rajasthan folks use it as a cure of stomach pain, arthritis, vomiting, piles diabetes and hypertension [28]. Folks employ the tender leaves for plastering boils, bark in intermittent fever and rheumatism, chew leaves for immediate relief in toothache, and take root powder for rheumatic pains [64]. Meenas use CD leaf for corneal opacity and roots for headache, tribals of southern Rajasthan apply root on scorpion bite, and take powdered coal from stem during fractured bone $[65,66]$. They eat flower buds to relieve stomache and flowers to sooth pain and increase erection [67].

In Haryana, the Khetawa Saperas of Jajjhar District use Kair for curing piles [68]. Folks in Gujarat use $\mathrm{CD}$ in a number of problems as toothache (application of two drops of young shoot juice in ear), rheumatism and eczema (application of paste of bark of kerda and mamejava (Enicostema littorale B1. on infected area). In Patan Gujarat, people use young root paste on scorpion bite, and fruit for cough and obesity [69]. In Cambay Taluka, folks use fruit powder orally for swelling, and piles [70].

In Sindh, Pakistan, people use whole plant in impotency, fracture of bones, wounds, alopecia, asthma, diabetes, skin infections ( ring worm, eczema), tooth ache and ear pain [71]. Immature fruits are taken to cure stomach problems and bark poultice for the wound treatment [63]. In Dera Ismail Khan, folks use ground fruit and sugar for rheumatism and pain of the body while in Bannu folks take ash mixed with ghee the same purpose [34]. 
In Algeria, Egypt, Libya, Morocco and Tunisia folks use $\mathrm{CD}$ as an astringent, anhelmitic, diaphoretic, antiseptic, antiasthamatic, dental, antiinflamatory as well as a laxative. They treat tooth ache, cough, asthma, inflammation, wound healing, boils, swelling, rheumatism, arthritis, skin and cardiac problems with CD [72]. Moroccans use fruit powder for diabetics [73].

Sudanese employ CD to treat skin problems, arthritis, articular pains, scramp, kidney pain, lameness, muscular inflammation, myalgia, sciatic, joint pain, stiffness, cancer and sprained and aching joints, [74], stomach problems, jaundice, headache and infections of joints $[4,75]$. They take decoction of CD flowers in sciatica, bark powder in cases of anorexia, indigestion and rheumatism [76] paste of young leaves and branches as plaster on boils and swelling [77, 78], decoction of fresh twigs against jaundice, the fumigation of the stems as anti-rheumatic. They use a poultice for swelling and joint pains and head-ache $[79,80]$ and roots to relieve fever, rheumatism and jaundice [81].

In Senegal people use plant as antipyretic and diuretic and take particularly in fevers, cysts and urogential problems [82]. In Somalia people consume leaves to treat cough [83].

\section{Veterinary}

CD offers many uses in animal ailments in Africa and Pakistan and India. It is used in anthrax, rheumatic pains, diarrhoea, scabies, ulcer, fractured bone and healing wounds and to de-worm animals.

Folks in Bannu, Pakistan, use the unripe fruit as anthelmintic for cattle and goats, a mixture fruit powder and sugar in rheumatism and diarrhoea and powder of tender branches mixed with wheat flour for pain [34, 63]. Tribes of Cholistan use fruits for treatment of diarrhoea, stomach ache, dysentery and loss of appetite [76]. In Euthpoia, folks use seed in anthrax and black leg disease [84] while tribes in Algeria, Egypt, Libya, Morocco and Tunisia use plant in scabies of camels [72].

Gujaratis apply powdered wood coal on the ulcer to minimise pain and help recovery [85], dry stem charcoal mixed with pure ghee to set the fractured bone of the animal [86] and a paste of tender branch in castor oil to heal maggot infested bleeding wounds in animals suffering from acute pain [87]. Folks tie floral primordia boiled in oil between the two halves of the animal hooves [88]. In Rajasthan, charcoal of roots mixed with sesame oil is given orally to animals for quicker healing of fractured bones, extract of fresh stem is applied on wounds for early healing and fruit is fed to goats to cure gastric problem [61].

\section{Scientific Studies}

Multifarious folk and traditional uses of Kair as food and medicine generated scientist's interest in number of countries. Studies have been conducted on its nutritional and photochemical contents to explore its potential.

\section{Nutritional Value}

Kair is a potential source of basic nutrients such as carbohydrates, proteins, fibres, minerals and vitamins $[89,90]$. Carbohydrates are the major constituent of CD fruits and buds followed by crude proteins and neutral fibres $[91,92,93]$. The ripened dry fruits contain 73.48 $\%$ carbohydrate, $14.94 \%$ crude protein, crude fiber (10.94\%, NDF $30.48 \%), 5.38 \%$ crude fat, $15.28 \%$ starch, $11.45 \%$ hemicelllose, $8.91 \%$ cellulose and $7.62 \%$ lignin. Available minerals include Phosphorus, Magnesium, Iron, Zinc, Copper, Sodium, Potassium, Manganese, Calcium, Selenium and Chromium [89, 94, 95]. Caper fruits and buds are as nutritious as many vegetables and fruits like banana and guava $[96,97]$. In addition to the minerals, the fruit and aerial parts contain vitamin $C$, vitamin A ( $\beta$-carotene), pthalic acid and oils $[89,96,98$, 99].

High quantity of $\mathrm{Fe}$ and $\mathrm{Zn}$ present in various parts is valuable to meet the deficiency in human nutrition. Iron is useful in prevention of anemia while $\mathrm{Zn}$ deficiency results in impeded growth and delayed sexual maturity [100,101]. Fruits are rich in K and possess optimum amount of $\mathrm{Na}$. The plants containing higher calcium and potassium contents are valued both for livestock feed and human food [102]. Both $\mathrm{K}$ and $\mathrm{Na}$ play vital role in role in maintaining the body fluidic balance, blood pressure, in intestinal absorption and nerve transmission. $\mathrm{K}$ and $\mathrm{Na}$ jointly improve the cardiovascular system as both of these are interconnected with one another and ensure smooth blood flow [103].

$\mathrm{CD}$ fruits contain only traces of Mn. It plays role in energy production and in supporting immune system [104] and its overdose may induce unfavorable effect on central nervous system (CNS) of the human beings [105]. CD fruits contain low quantity of anti nutrients (mg /100g) such as phytic acid (112.8), polyphenol (2.3) and oxalates (310) and their levels can be reduced by dipping the fruits in salt water (common rural practice) and in fermentation process. Fermentation improves the nutritive value of the fruit by remarkably decreasing the anti-nutrients and enhancing availability of $\mathrm{P}$ and $\mathrm{Fe}$ [106].

CD seeds are rich source of all three major food components, i.e carbohydrates (25.42\%), lipids $(29.11 \%)$ and proteins $(27.71 \%)$ and $20 \%$ of high quality edible oil [107]. Seeds possess sufficient amounts of both essential and non-essential amino acids as glutamic $(24.01 \%)$, aspartic acids (11.91\%), methionine (0.75 \pm $\%)$, cysteine $(0.34 \%)$ and ariginine $(3.46 \%)$. Seed oil contains minerals such $\mathrm{P}, \mathrm{Na}, \mathrm{Mg}, \mathrm{Fe}$ and $\mathrm{Ca}$ and fatty acids (linoleic acid and eicosenoic acid) [107]. Linoleic 
acid prevents cardiovascular disorders such as coronary heart disease; atherosclerosis, as well as hypertension [108]. Arginine is involved in rapid regeneration of adenosine triphosphate, cell proliferation, vasodilatation, neurotransmission, calcium release and imparting immunity [109]. Seed oil is a healthy source of fatty acids and can be used in diet. The presence of reducing sugar, fats, vitamin $\mathrm{C}$, antioxidants, alkaloids, and carotene makes it a dietary supplement [110].

The heavy metal contents of edible parts of CD (< 1mg kg-1. Cd, Co and Ni content) is less than the limits suggested by WHO for medicinal plants. High mineral and fibre content and low heavy metal and anti-nutrient content in edible parts make the fruits suitable for food products $[22,38,100]$. These attributes make the plant all the more desirable to be included in healthy and green diet.

\section{Phyto-Constituents}

CD plant contains alkaloids, flavonoids, tannins, saponins, resins, glycosides, terpenoids, phenols, sterols, essential oils and vitamins that impart it with various pharmacological activities, medicinal properties and nutritive value. These activities include: antioxidant, anti inflammatory, hepatoprotective, anticancer, analgesic, wound healing, anti hyperchloestimia, anti-parasitic, anti-microbial, antiviral; anti-arthritic, insecticidal, anti-allergic and anti-cancer and anti-arthritic (Table-2).

Table-2: Phyto-constituents and Pharmacological activity of Capparis decidua *

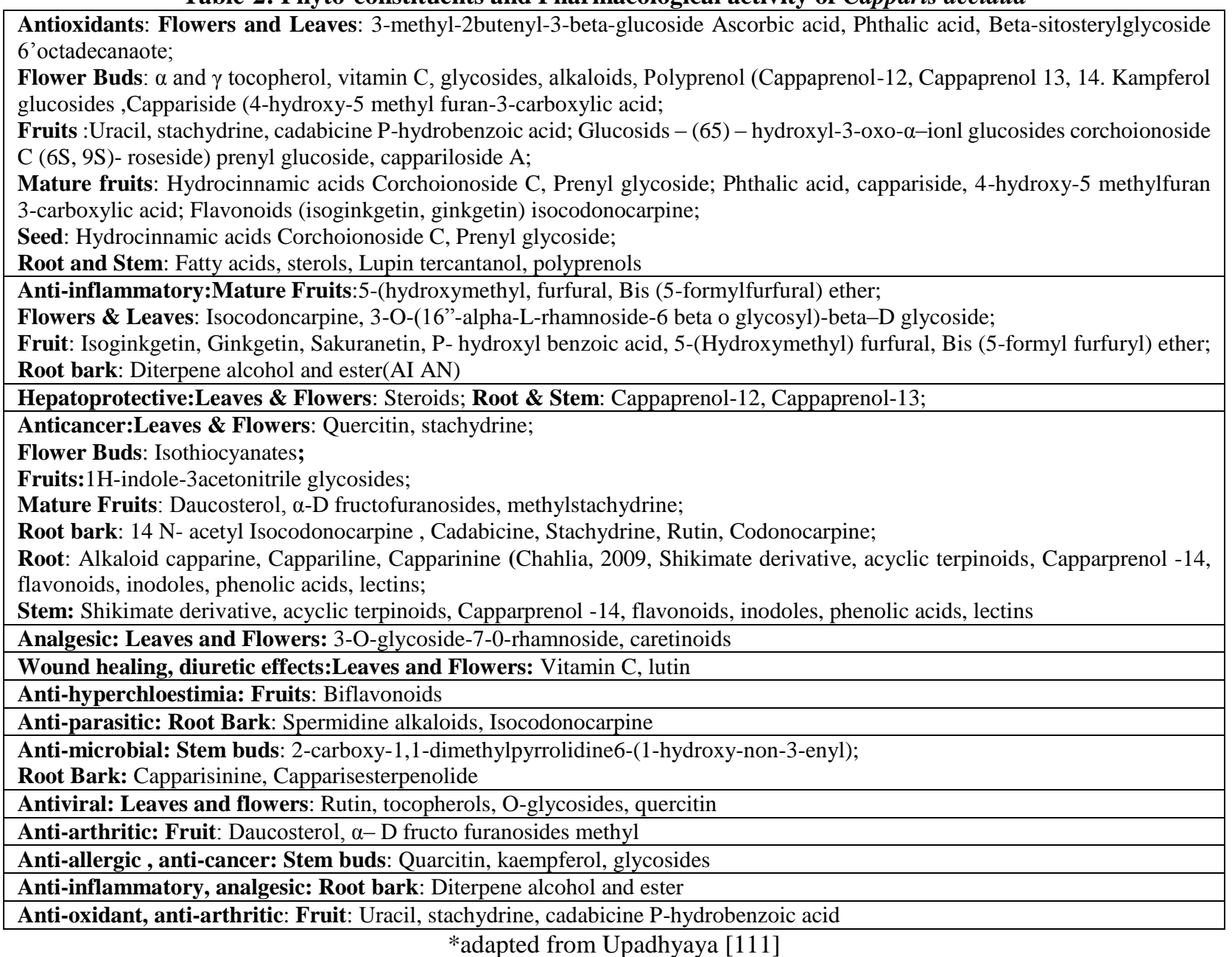

Flower buds are endowed with tocopherol, vitamin $\mathrm{C}$, glycosides, alkaloids that are anti-oxidants and isothiocyanates which are anticarcinogenic. Fruits contain biflavonoids which exhibit anti-hypercholestrolemic activity and daucosterol, uracil, stachydrine are anti-arthritic. Flavonoids, isoginkgetin (I), ginkgetin $(\mathrm{G})$, isocodonocarpine possess antioxidant property; 5-(hydroxymethyl, Bis (5-formylfurfural) ether present in mature fruits have anti-inflammatory property [111]. I and $G$ act as anti-aging agent and also reduce the skin sebum level [112]. Phenolics of fruit impart wound healing, antibacterial, anti-viral activity [113].

Roots have Capparisinine and Capparisesterpenolide that have anti-microbial property while Cappaprenol-12 and Cappaprenol-13 are hepatoprotective in action (Table-2) [111]. 
Capparidisine has a depressant activity and a has dose dependant effect on heart rate and on coronary flow [114]. Isocodonocarpine, and spermidine alkaloids occurring in stem and root bark are effective in treating asthma, inflammation, gout and cough [115, 116]. Flavonoids, steroids, triterpenes, diterpenes, alkaloids and tannins are potent analgesic and have antinociceptive activities [117]. Seeds possess fatty acids, tocopherols, sterols, proteins which are nutraceutical. Lactone flavnoids (sesquiterpine lactones: MW-6 and MW-11) present in aerial parts are potent antiplatelet [118]. Isothiocyanate aglycon (glucosinolate) in seeds shows significant antibacterial activity [119] against Vibrio cholerae, V. ogava, $V$. inaba and $V$. eltor cholera causing bacteria [120].

High level of saponin (glycosides) in fruit directly correlates with its use as a medicine for various ailments such as cancer, rheumatism [121]. The cytotoxic activity of $\beta$ sitosterol triacontenate (ester) found in stem is as efficient as Paclitaxel used for chemotherapy in breast cancer [122]. Anti-invasive and anti-metastatic nature of stachydrine, in fruits and different terpenoids of root bark and stem make $\mathrm{CD}$, a competent candidate for use in the development of anticancer drugs [122-124].

\section{Scientific validation of Traditional uses}

A number of activities attributed to CD plant parts in various Ayurvedic treatises have been proved and authenticated by pharmacological tests. These include: arśoghna (anti piles), śophaghna (anti-inflammatory), śvāśaghna (antiasthmatic), sarvashulanashak (analgesic), hrdya (cardioprotective) anasthematic, purgative, ant-helmintic, yakritjit or hepatoprotective, astringent, neutraceutical and antimicrobial activities (Table-3A.) In addition, some of the folk uses as antidiabetic, anticancer, antiviral (herpes), and hypertension, have also been proven and authenticated (Table-3B.). However, some of Ayurvedic and folk (Table-3C), Ayurvedic and Greek uses (3E) have not been yet authenticated by pharmacological tests.

Table-3A: Ayurvedic, Folkloric uses and Pharmacological activity of Capparis decidua

\begin{tabular}{|c|c|c|}
\hline Ayurvedic and Unani /Greek uses & Folk Uses & Pharmacological \\
\hline swashara 49, śvāśaghna (Antiasthmatic) 46 & Asthama 72,149 & \multirow[t]{2}{*}{ Antiasthmatic 129} \\
\hline Asthama chronic respiratory & Anti-rheumatism, 80 artheritis 28 & \\
\hline $\begin{array}{l}\text { Purgative/laxative } 49 \text { Increases stool flow } \\
53\end{array}$ & Cathartic purgative 72 & Purgative 130 \\
\hline \multirow[t]{4}{*}{ Hṛdya (Cardioprotective) 46,50} & Cardioprotective 72 & Hypolipidaemic 131, 132,133 \\
\hline & & Antihyperlipidemic 132,133 \\
\hline & & Anti-atherosclerotic 132 \\
\hline & & Antispamatic, muscular contraction 142 \\
\hline yakrtajita (Hepatoprotective*46 & lever function,jaundice 125,126 & Hepatoprotective $134,135,136$ \\
\hline tonic & tonic & Nutraceutical \\
\hline Antimicrobial\#50 & Skin infections 74,149 & Antimicrobial 136 \\
\hline Antibacterial@53 & & Antibacterial 137 \\
\hline Anthelmintic cv\#@50,53 & Antihelmenthic 72,127 & Anthelmintic $120,130,138$ \\
\hline Janthughna anti animal & Antiparasitic & Anti parasitic 139 \\
\hline Bronchial disorders Expectorant@53 & Cures cough 72 & Bronchodilatory 140 \\
\hline $\begin{array}{l}\text { Discutient sothhara\# } 50 \\
\text { tumour, swelling inflamation \#50 }\end{array}$ & tumours10; inflammation 74 & Anti inflammatory 140,141 \\
\hline Anodyne vedanasthan\#@ 50, 53 & $\begin{array}{l}\text { Pains: Ribs, Spleen, joint, } 62 ; \text { sciatica, } \\
\text { toothache } 72,149 ; \text { Stomach } 28,80 \text {, } \\
149 \text {; Ear, Body } 149\end{array}$ & Analgesic and anti-nociceptive activity 117 \\
\hline $\begin{array}{l}\text { Sarvashulanashak (Analgesic) 46, pain } \\
\text { reliever 50, 53 }\end{array}$ & analgesic72 & \\
\hline $\begin{array}{l}\text { Astrigent 53stops bleeding, makes skin less } \\
\text { oily }\end{array}$ & Astringent 72 & Antisebum cream 112 \\
\hline Haemostatic 50 & Piles, Haemostaic 72 & Ant platelet 118 \\
\hline Piles and Haemoroids 50 & Blood in stool ;blood from nose & \\
\hline Vrananāśaka (wound healing activities) 46 & Plastering boils 63,149 & \\
\hline \multicolumn{3}{|c|}{ 3B. Folk uses Proved by Pharmacological testings } \\
\hline & Anti Diabetes 28,149 & Antidiabetic (AD)142, Hypoglycemic 143 \\
\hline & Anticancer 74 & Anticancer 122,123 \\
\hline & & Antioxidant 133, Anti-aging 124 \\
\hline & hypertension 28 & Depressant 114 \\
\hline & & Depressant \& anticonvulsant 144 \\
\hline & & Hypotensive, spasmolytic 145 low pressure \\
\hline & Antifertility (male) & Rubifacient, vesicant, antisterogenic 146,147 \\
\hline & Antagalic headache 80 & Antihypertension 148 \\
\hline
\end{tabular}


Ahuja, S. C et al., Sch Acad J Biosci, Nov, 2020; 8(11): 378-396

\begin{tabular}{|c|c|c|c|}
\hline & \multicolumn{2}{|l|}{ Halitosis fetid breath } & Use in mouth fresheners 28 \\
\hline & \multicolumn{2}{|l|}{ Hypoglyceamic 33} & Hypoglycaemic \& AD 132 \\
\hline & \multicolumn{2}{|c|}{ Stomach problems 80 dysentery } & $\begin{array}{l}\text { Antiparasitic,antibacterial } \\
\text { ( Cholera) } 120,130\end{array}$ \\
\hline & \multicolumn{2}{|c|}{ Herpes 74} & Antiviral 111 \\
\hline \multicolumn{4}{|c|}{3 C. Uses/ Activities Known in Ayurveda \& Unani and Folk Medicine, But not Proved } \\
\hline \multicolumn{2}{|l|}{ Ayurveda \& Unani } & \multicolumn{2}{|c|}{ Folk Medicine } \\
\hline \multicolumn{2}{|c|}{ Diaphoretic/sweat ( svedopaga) 50, 53;Sudorific,53 } & \multicolumn{2}{|c|}{ Diaphoretic 72} \\
\hline \multicolumn{2}{|c|}{ potherb } & \multicolumn{2}{|c|}{ potherb } \\
\hline \multicolumn{2}{|l|}{ scorpion bite } & \multicolumn{2}{|c|}{ scorpion bite } \\
\hline \multicolumn{2}{|l|}{ Renal disinfectant, diuretic, Increases urine } & \multicolumn{2}{|c|}{ Renal disinfectant diuretic 128 , Urinary problems } \\
\hline \multicolumn{2}{|l|}{ Aphrodisiac 53;Stimulant 53+ } & \multicolumn{2}{|c|}{ impotency 8128 sexual problems 8128} \\
\hline \multicolumn{2}{|l|}{ Eye diseases } & \multicolumn{2}{|c|}{ Night blindnedness 128 Eye problems $33,49,63$} \\
\hline \multicolumn{2}{|l|}{ Chardighna (Anti emetic), vomiting 46} & \multicolumn{2}{|c|}{ vomiting 28} \\
\hline \multicolumn{2}{|l|}{ intermittent fever } & \multicolumn{2}{|c|}{ Intermittent fever 149} \\
\hline \multicolumn{2}{|c|}{ Carminative } & \multicolumn{2}{|c|}{ Expelling gas from relieve, colic 53} \\
\hline \multicolumn{4}{|c|}{3 D. Activities Proved by Pharmacological Tests } \\
\hline \multicolumn{4}{|c|}{ Epilepsy Sedative and anticonvulsant effects 144 abnormal violent involuntary contractions } \\
\hline \multicolumn{4}{|c|}{ 3 E. Ayurvedic and Greek Uses Only, not verified by Pharmacological Tests } \\
\hline \multicolumn{4}{|c|}{ Emmenagogue artavotpadaka 50; Amenorrhoea, dysmenorrhoea, painful mensuration 62, 63} \\
\hline \multicolumn{4}{|c|}{ Chronic poison; Digestive 50 arucināśaka /Appetizer 46,53; Thermogenic 53} \\
\hline
\end{tabular}

\section{Possible future uses}

\section{Broad Spectrum Pesticide}

CD exhibits broad spectrum biological activity due to presence of bioactive phytochemicals like alkaloids, terpenoids, glycosides, flavonoids and fatty acids. The plant shows activity against fungi, bacteria, virus, amoeba, insects, mollusks and helminthes [150, $151]$.

It is also highly toxic to white termite Odontotermes obesus [152]. Solvent extracts of CD are active against storage insects like Sitophilus oryzae, Rhizopertha dominica, Callosobruchus chinensis, Tribolium castanaeum. While stem and flower extracts show activity against beetle, Bruchus chinensis, a sorage pest of pulses and crop pests like Spodoptera litura (cut worm of tobacco/ cotton leaf worm), Heliothis armigera (boll worm of cotton) and a mite Tetranychus urticae Koch, a common pest of a variety of plants $[139,153$, 154].

CD also shows activity against vectors of human diseases such as yellow fever and fascioliasis. $\mathrm{CD}$ extracts show high toxicity against larvae of yellow fever mosquito, Aedes aegypti [154]. Alcoholic extract of flowers is lethal to snails, Lymnaea acuminata Lamark and their cercarial larvae [155]. Snail is a vector of liver flukes, Fasciola gigantica Cobbold and F. hepatica L. responsible for endemic fascioliasis in cattle and humans.

In addition to storage insect pest, $\mathrm{CD}$ is effective against storage fungi being antifungal against seed borne pathogenic fungi like Aspergillus niger, A. flavus, Fusarium moniliforme, Phytophthora sp., Penicillium sp. and Mucor sp [156].

\section{As Antibiotic}

Alcoholic extract of fruit husks, seeds and flowers possess antibacterial activity [136]. The ethyl acetate extract of plant has anti-bacterial activity against Gram-positive and Gram-negative bacteria, the n-butanol extract displays inhibition against Pseudomonas pneumoniae and Escherichia coli while chloroform and ethyl acetate extracts are potent against Giardia with efficacy comparable to metronidazole drug. All extracts show no toxicity against brine shrimps and vero cell lines suggesting safety for traditional use [157].

\section{Prediction of antimicrobial/insectidal herb on basis of Ayurvedic determinants}

Review of literature on pharmacological testing reveals that $\mathrm{CD}$ possesses anti-worm and antimicrobial properties. Karira is katu (bitter) and teekta (pungent) in taste, katu (pungent) in the Vipaka (transformed taste /post-digestive effect), ushna (hot) in veerya (potency) and laghu (light, L) and rooksha (dry, D) in guna (quality) [46]. Plants with combination of LD, LDP (teekshna, penetrating), LPSo (soothing, snigdha), LDPM (mobile, sara) and LSo quality possess insecticidal and antimicrobial activities [158]. This prediction on basis of Ayurvedic determinants is corroborated by earlier findings [139, 157]. Similar predictions for Vitex nirgundi and Cordia dichotoma $[159,160]$ stand corroborated by pharmacological testings.

\section{Bio- inhibitor of Corrosion}

Capparis decidua extracts can work as non-toxic, biodegradable bio- inhibitor of Aluminium and copper corrosion and can replace toxic chemicals in use for this purpose [161]. Seed extract is an effective inhibitor for copper in acidic medium. The adsorption of Capparis decidua seeds is spontaneous, physical in 
nature and is an effective eco-friendly corrosion inhibitor with significantly high inhibition efficacy $(94.60 \%)$ for copper in $0.5 \mathrm{M} \mathrm{HCl}$ and can be a good replacement for many chemical constituents to be used as corrosion inhibitor [162].

\section{Anti -aging Cosmetic}

Seed, flower bud, flowers, leaf, stem and roots of $\mathrm{CD}$ contain antioxidants that act as anti-aging agents and can be used in anti-aging cosmetics [124]. A cream formulated from CD plant extract is useful for people having oily skin and problem of acne or seborrhea due to excessive secretion. This cream controls the excessive sebum secretion and is free of any adverse effects of strong antibiotics, steroids or products containing strong chemicals [112].

\section{Source of Bio-diesel}

CD seeds yield $63.75 \%$ percent biodiesel (in oil fraction). The optimum temperature for in-situ transesterification is $80^{\circ} \mathrm{C}$. The agitation was achieved by keeping $300 \mathrm{rpm}$ oscillations continuously for 60 minutes optimized time [163].

\section{Use in Green Nanotechnology}

Kumari et al., [164] synthesized green silver nanoparticles by using ethanolic extracts of the whole plant as a reducing agent. This is a convenient method, clean, environment-friendly, and better than the conventional chemical methods, provides faster rates of biosynthesis and can potentially be used in areas of cosmetics, food, medicines and antibacterial agents [165].

\section{Natural pH Indicator}

An ether extract of flowers may serve as a natural $\mathrm{pH}$ indicator and a substitute of synthetic indicators, with advantages of being low, cost, simple and without any risk of environmental pollution [166].

\section{Recent Advances in Breeding and Improvement}

$\mathrm{CD}$ is an open pollinated plant and wide genetic variability exists in the natural population. The plant shows marked diversity in plant types, spine, canopy (spread and compactness), flowering (time of flowering, colour of flower), and fruiting (size and colour of fruits) characters. A germplasm collection from rocky, gravely, sand dunes, natural rangelands and cultivated fields of arid regions (Jaisalmer and Barmer districts) of Rajasthan showed two distinct plant types as: shrub with large canopy spread and a small tree form having more than $5 \mathrm{~m}$ height with flowers of light red to scarlet red, and occasional plant with yellow flowers and mature fruits of variable size and colour. Forty-five collected accessions exhibited wide range of variability for fruit diameter, fruit weight, number of seeds per fruit, test weight and canopy characteristics [167]. CIAH (Central Institute of Arid Horticulture) with collaboration NATP-PBD of NBPGR, New Delhi (1999-2004) collected 64 elite germplasm of Ker from semiarid and tribal area of Rajasthan and Gujarat. At present 32 types are conserved in the National Field Repository of CIAH at Bikaner. Krishna et al., [168] felt dire need to identify suitable types that are heavy yielding, possess large fruit size and high pulp content, rich in protein; with proper total soluble solids (TSS), tartness, less acrid, with small and soft seeds. So far, a promising genotype CIAH-Thornless-1 has been identified [169].

\section{Causes of Depletion in natural population}

$\mathrm{CD}$ is at risk due to human as well as natural factors. Lack of seed production due to irrational picking of high value immature fruits is one of the major factors. Natural factors include the small period of seed viability, and natural competition faced with Prosopis juliflora, that regenerates faster and grows aggressively [170]. The plant has been listed as one of the endangered species in India [171].

Moreover, the conventional methods of propagation like grafting; layering and cutting are of limited applicability and involve risk of the exposure to pests, diseases, and soil or climatic stresses. In addition to short period of viability seeds have the shorter storage span due to desiccation-sensitivity and pathogenic infestation. Therefore, the tissue culture technique becomes important for mass propagation of plant and synthetic seed via encapsulation technology offers an important alternative.

A protocol for in vitro propagation of $C D$ via tissue culture was developed to produce superior planting stock for various afforestation and reforestation programmes [172]. Recently, Ahlawat et al., [173] utilized synthetic seed by using the shoot tips and nodal segments from in vitro cultures for encapsulation. This technique seems practical for short term storage, and production of synthetic seed to be released for commercial purposes.

\section{Folklore}

Being a prominent and useful tree it has occupied a place in folk culture of desert areas. Caper has penetrated in local language in Rajasthan, Bundelkhand and Haryana, through riddles, sayings and folk songs. The references of its wood quality and thorn occur in proverbs in different social contexts. It has been used to convey the bad nature of a person, relationship of wife and co-wife, and bad behavior/attitude of mother-in-law. Though a thorny plant it attracted the attention of a number of poets of Bhakti sect and appears in writings and poems of Surdas, Raskhan, Rahim, Kabir and Tulsidas.

\section{Use in Rites de passage}

Kair/Karir is considered holy and is associated with the religious rituals of the local population of Thar Desert. It is found growing near or around religious 
places. It is customary for a newlywed couple and new born to offer prayers in front of a Kair plant. Its stems find use in preparation of Turan during marriage ceremony and as firewood during havan (fire sacrifice) [61]. It is one of the 19 plant species on which $58 \mathrm{Sikh}$ shrines have named. The naming of sacred shrines after trees is unique to the Sikh religion and at Gurudwara Karir Sahib in Littar, Ludhiana; devotees seek blessings for child [174]. It is also associated with graves and cremation ground [12].

\section{Religious Uses}

Kaustaka Sutra mentions use of the powder of Karira fruits for Kariri ritual, performed to ward off drought [14]. In religious sacrifices, saktu of the fruits (powder of the dry and parched fruits) is used. In Mahabharata, the use of long bottle gourd, Kalasaka (curry leaf), Slemastaka, Sudersana (?), leaves of Bamboo or Karira is interdicted [13].

\section{Indicator of Groundwater in desert land}

Upavana Vinoda mentions that the presence of Karira with badri (Semecarpus mauritiana) tree serves as indicator of underground water and presence of a bilva (Aegle marmelos) or Karira tree in combination with a kakubha (Terminalia arjuna) tree indicates very sweet water at a distance of two hands at the depth of twenty five man height. While an anthill in North of a Karira tree indicates sweet water to the south at a depth of ten man height $[175,176]$.

\section{Climate Indicator}

Kair and Kachri (Cucumis melo agrestis) are considered as the climate indicators in arid zone. A fully Kair laden with thorn, flowers and fruits indicates drought and high temperature while in a good season it bears only average flowers and fruits. Similarly, in Gujarat, the farmers of Surender Nagar, Kheda, Bhavnagar and Ahmedabad use kerda in predicting weather, temperature and rainfall. They perceive that greater blooming deep pink flowers in colour the temperature will be more than $45^{\circ} \mathrm{C}$ and less rainfall [12].

\section{Indicator of Rain}

A Bundelkhandi proverb indicates the signs of the approaching rain "Bhal bhal bake papaiyo bānn̄, kūfl kair taṇi kamalāṇī, jal hal to ūge ravi jāṇ̄ pahrān māyan avsare pān $\vec{\imath}$ ' [177]. If a crusted cuckoo moves around chirping, new leaf of kair withers, and there is intense heat of sun at Sunrise, then it should be understood that it will rain in a moment.

\section{Indicator of Cotton Yield}

"Akian, niman bajra, kairarian kopas. Jo phale jal to jowar hone ki as" There shall be bajra (pearl millet) if there is ak (Calotropis), Cotton when there is kair, and there is jal fruit (Salvadora), there is hope of jowar (Sorghum) [178].

\section{Names after Karil}

A number of villages owe their name to Karir. Kair village in Najafgarh District of Delhi state, Karil and Tient in Hatras District of Uttar Pradesh, Kario Ki Dhani in Danta Ramgarh Tehsil in Sikar District of Rajasthan are named after Karir. Kair is name of a village in Iran also.

Two Jat Gotras Karil and Karir of Rajasthan and Haryana and Karerai/karai/karer clan of Afghanistan owe name to this plant and it is a totem of Karir gotra [179]. Karirs get name from being living in the Karir forests on Saraswati River during Mahabharata period. Similarly, Karils were inhabitants of region surrounded by Karil trees [180].

\section{Defining area}

$\mathrm{CD}$ has been used to demarcate Marwar because of its abundant occurrence. Being a desert tree growing under harsh conditions and area considered hard to live; is evident in the following pray.

A girl prays to his grandfather and says not to marry her in Marwar (Jodhpur area): O Grandfather, do not marry me to a person of Marwar, Even if I may remain unmarried. Houses inside deep desert, the land having snakes, Thorny Karil are its trees. $A k$ (Calotropis) and phok (Calligonum polygonoides) only provide shade, satisfy hunger by eating grass seeds [181].

Raja Bheem used names of plants to distinguish his land from that of enemy in Rajasthan and said "Wherever Aonla (Cassia paniculata) puts forth its yellow blossoms, the land is right ours: we want nothing more, let them enjoy their stunted Babuls (Acacia), their Kureels (Capparis decidua), the ak (Calotropis procera) but give us back our scared Peepal (Ficus religiosa) and Aonla of the border" [41]. Here plants are used to distinguish Mewar (Udaipur area) from Marwar, English rendering would be "Cassia auriculata characterises Mewar, whereas Acacia nilotica sp. India characterises Marwar".

Likewise in Mathura is known for Kair, as the following couplet of Tulsidas indicates:

Radhe Radhe rathat hain, Aak, Dhak aru kair, Tulsi ya braj bhumi main kaha Ram se bair. (It is said that once Goswami Tulsi Dass visited Mathura. There he found every one worshipping Radhe Krishna, and nobody discussed or remembers Ram, since the three plants (Ak, Calotropis procera, Dhak, Bauhinia variegata and Kair), commonly grow in the area, so it is used as a metaphor to convey in sense everyone).

Kahūim kahūim bhagwān kī gaī sitilapau nahi,

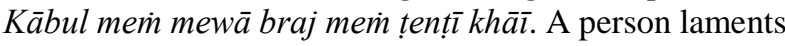
and says that at some places God's irregular/ improper ways do not cease, He has provided grapes in Kabul and 
tenti to Braj people. What kind of justice is this? Kabul mei் mewa kiyo kiyo braj mem karil [182].

\section{In Folksongs}

Ker appears in Huns songs of Rajasthan relating to the wishes of a pregnant lady. There are specific Huns songs associated with eatables as Ghevar (a Rajasthani cuisine sweet traditionally associated with the Teej Festival), ker, and water melon. The one on Ker runs as follows:

Lagyou dhan nai palo ji maas, par chhaya suhavai

$O$, mharai sasur ji rai haath $j i$

Bhavai dhan nai fina roti dal, keriya to bhavai O Jachha rani nai chhapar valai taal ra" [183].

A pregnant lady says to her husband "It is first month of pregnancy oh! Son of my father-in-law, my heart goes for few things. Husband replies that you are daughter of a big house. Oh! Lucky -future mother-to-be, I shall fulfil your heart's wish. She doesn't feel like eating tasteless bread and pulse and feel like eating the vegetable of keri. Husband replies I have acquired keri from village Chappar vali taal.

\section{In Bhakti sangeet}

Raskhan (Syed Ibrahim Khan (born 1548 A.D.) a Pushtun and devotee of Lord Krishna says "Raskhan Kabaum in āmkhin som, braj ke ban bagh taḍag nihāraum; kotik hū kaldhaut ke dhām, karil ke kumijhan úpar vāraum." I want to gaze the forests and gardens of Braj with my eyes throughout my life time, so much so I want to sacrifice my hundred palaces made of gold for sake of thorny bushes of Karil. Uncountable palaces made up of Gold can be sacrificed upon bowery alcoves of Braj [184].

Oh Rahim! Where are those trees having good shade, in gardens we see sehumr (milk -bush, Euphorbia tirucalli), kutaj (easter tree, Holarrhena antidysentrica) and karir. Rahiman ab ve vrich kaham jinki chämh gmbhir, bagan bich-bich dekhiyat sehumr, kutaj, karir.

\section{Proverbs}

Baiṭhno chhāyā maim bhalāim kair hī, rahṇo bhāyān maìm huo bhalām bair hi. Sit in shade even though of kair, and live with brothers even though envious.

Kair ki thümțth țut jyāgo, lulaigo nahin. The wood of Karil will break but won't bend. A bad fellow may afford a loss but does not leave his adamancy (unreasonable resistance) [185]. A variant of proverb is "Kair kā kāth tūṭai paṇ lulai koṇīn" [186]

A proverb is prevalent in Haryana, Punjab, Bundelkhand and Rajasthan describes the nature of karir thorn and compares it with the co-wife:

Kanta bura krill ka, au badly ka gham

Saukan buri hain chun ki, aur sanjhe ka kam
Thorn of Capparis; Sun at the time of clouds; a co-wife (even of wheat flour), and partnership in business; these four things are bad. Another version of the proverb is available "Kanțo sāle karīl kau, ur badarauțā ghām, larkā sāle saut kau, ur sāje kau kām[187-190].

The tongue of the man of bad words is compared with thorns of caper "Jhibh nai kair ko kataujhibh ko kair ko kanto- It is not tongue but thorn of Capparis. A speaker of bad words is cursed with these words. The bad tongue pricks like karil thorn [190].

Thore muhm mem kair rau kantau-Tere muhm memkair ka kanta- A speaker of bad words is cursed with these words. A person whose words prick like a karil thorn is cursed like that [190].

Kāla muhṁ karīl ke dānt. Face is black and has teeth of Karil (karil prick of karil thorns are very painful [177].

A Bundelkhandi proverb persuades to work hard till your wish is not fulfilled. Jaulaun phūle ketki taulon bilam karìl- Until your heart wish is not fulfilled up to then go on working something or other [182].

Apat karīr nā mahūlīai de doṣ basante. When karir does not flower then what is fault of the spring season. If a bad person does not show good then why to find fault with a good person [191]. Another version of the Punjabi proverb runs as "Karīl jau na phūlau, basantu ca una üllai mat and hatras" If Karil does not flower in spring season, then why spring should not enjoy.

Kair alo i balai, sasu sudi $i$ ladai [186]. In Punjabi it runs as Karīr gila vī saṛe, sas garībaṇi vi lare-It known fact that only dry wood burns or catches fire- but karir is an exception as wet its wood burns. Karir is compared to a mother-in-law and an officer. Howsoever she may be kind, getting a chance she becomes angry and says hot and bad words. Whatever sort officer he gets angry on the subordinate. To show off right it is a natural human instinct.

Karīl kau kamṭo, sāọhe sorā hāt lāmbo [186]. Bundelkhandi version runs as "Kair rau kamiau giyo saḍi solai hāth" The thorn of karir is very small and soft. If it grows up to sixteen hand lengths then it is like a day -dream. It is said so for a person who talks gossips [182].

Kair sūm chuṭa to kūmatiyo mem paḍiyau- Out of Karil (which has two thorns) went into Kumatiyo (Acacia senegal) having shiny dark red spines in sets of three, with one thorn hooked like a parrot's beak gum. Out of frying fan into the fire. From a bad situation to one that is worse. 
Dhān khāvai ke ker khāvai- eats grain or Capparis -Said so to a person who acts like a foolish [190].

\section{A Bundelkhandi Riddle \\ Ek rukh saraua. Larkan ki kilar bilar, pattan ki duniya-Answer - Karir [182].}

\section{Karil in Epic of Mahabharata}

There are references to Karir in the great epic poem of Mahabharata. Karna Parava points out to tree species as Sami (Prosopis cineraria (L.) Druce), Pilu (Salvadora olcoides Dence) and Karir growing along the bank of Saraswati River, and forest having many pleasant paths of the above said trio and mentions other kinds of trees on the banks of the Saraswati [193].

\section{Discussion and Outlook}

Hippocrates nearly 2500 years ago said so "Food is the medicine and medicine is the food" (Proper diet is the medicine and there is no medicine like proper diet). Even good medicines will not cure a patient without an appropriate accompanying diet. Capparis fits into the Hippocratic criteria of food being a nutraceutical food having therapeutics activity against a number of ailments.

Plant provides nutritious food and finds extensive uses in folk medicine and traditional systems of medicine in various countries. It can provide essential nutrients as carbohydrates, protein, fats, mineral and fibre in appreciable amounts. The mineral content of the plant is high while heavy metals (i.e., Ni, Co and $\mathrm{Cd}$ ) in traces. Fruit is rich in $\mathrm{K}, \mathrm{Fe}, \mathrm{Zn}$, has low content of $\mathrm{Na}$ and only traces of $\mathrm{Mn}$ and anti-nutritional factors making it a good source of nutrients and valuable to meet the deficiency of these minerals in human nutrition.

Many parts of the plant possess natural antioxidants and nutraceuticals (Table-2). The plant is endowed with phytoconstituents such as alkaloids, glycosides, terpenoids, sterols, flavanoids, phenols and fatty acids that lend the plant with medicinal values as hypercholesterolemic, anti-inflammatory, analgesic, depressant, antidiabetic, hypolipidaemic, antiatherosclerotic, anti-helmintic, purgative, hepatoprotective, antihypertensive, rubifacient and vesicant activity.

Although many of pharmacological activities attributed to plant (Table-3) has been authenticated, yet some traditionally and folkloric medicinal uses like aphrodisiac, diaphoretic, anti poison, diuretic, antiemetic and emmenagogue need investigation in this regard. Capparis also shows potential for use as a male contraceptive, anticancer, anti-aging and cosmetics $[124,146]$. In spite of the innumerable folk, traditional uses and pharmacological verifications, little attention has been paid so far on the preclinical and clinical studies [31].

In addition to its nutraceutical value the plant may serve as future source of green bio-diesel, nanotechnology, inhibitor of metal corrosion and as an antibiotic.

CD possesses a broad spectrum activity against amoeba, fungi, bacteria, viruses, snails, termites, ticks and other insects. It qualifies as a good insecticidal plant and its active ingredients could be used for preparation of herbal or bio-pesticide formulations for control of flying and stored grain insects and termites. Certainly, $\mathrm{CD}$ may prove as a source of nutrition, medicine and herbal pesticides in future as envisaged earlier [139].

Capparis decidua is an important constituent of desert ecosystem. Plant offers multifarious uses as food, feed, fuel, wood, medicine and plays important ecological roles. Being tolerant to temperature, salt and drought stresses it provide vegetation cover and helps in arresting on sandy wastelands. The plant also improves the fertility of sand dunes and reduces alkalinity [3]. It has good soil binding capacity and can be used in landscape gardening, afforestation in semi desert area to prevent soil erosion [170].

Borrowing words of Meghwal and Tiwari [36] "Kair offers scope for commercial cultivation on marginal lands under rain-fed conditions because of its adaptability to grow in different soil types in arid areas with very low and erratic rainfall. It is a very strong candidate for use in both plantation forestry and agroforestry (as a woody component), and even for horticulture".

Primary area of attention would be stabilising and sustaining natural population. The plant is overexploited due high economic value of immature fruits and are often harvested and sold at high prices. This practice puts seed production and progress of Kair at risk. Poor and lack of seed production continue to be the major cause for declining Kair population. The seeds have short period of viability and short storage span and propagation of plant through seeds is poor. The plant has been even listed as one of the endangered species of India [171].

There is dire need to awaken and educate the younger generations about the preservation, promotion and use of this precious little berry. This objective demands joint 1 efforts of people, relgious leaders, policy makers, scientists and NGO's for protection of the species and save from undue importance given to import by western media and modern chefs. Our own valueable plants are losing ground due to lack awareness and information usefulness of small berries. 


\section{REFERENCES}

1. Heywood VH. Flowering plants of the world. Oxford University Press, London, 1978, 335

2. Meghwal PR. Judging the culinary maturity of ker fruits (Capparis decidua). Curr Agric. 2002, 26:7576.

3. Gupta IC, Harsh LN, Shankaranaryana KA, Sharma BD. Wealth from wastelands. Indian Fmg. 1989, 38(11):18-19.

4. Satyanarayanan T, Anjana AM, Vijetha P. Phytochemical and pharmacological review of some Indian Capparis species. Pharmacognosy Reviews. 2008, 2(4):36-45.

5. Singh M, Jindal SK, Sivadasan R. Capparis decidua - a multipurpose shrub. In: Narain P, Singh M, Khan MS, Kumar S (Eds) Shrubs of Indian arid zone. Central Arid Zone Research Institute, Jodhpur, 2005, 97-104.

6. Chundawat BS. Few economic shrubs and their commercialization. In: Narain P, Singh MS, Khan MS, Kumar S (Eds) Shrubs of Indian arid zone. Central Arid Zone Research Institute, Jodhpur, 2005, 131-135.

7. Malik SK, Chaudhury R, Dhariwal OP, Bhandari DC. Genetic resources of tropical underutilized fruits in India. National Bureau of Plant Genetic Resources, New Delhi, 2010; 38-46

8. Sharma PV. Namrupajnanam. Characterisation of medicinal plants based on etymological derivation of names and Synonyms. Satyapriya Prakashan. Varanasi. 2000, 213

9. Pandey AN, Rokad MV. Sand dune stabilization: an investigation in the Thar desert of India. Journal of Arid Environments. 1992, 22(3): 287-292.

10. Maydell VJH. Trees and shrubs of the Sahel. Their characteristics and uses. Deutsche (GTZ). Eschbor. Germany. 1986.

11. Shankarnaryan KA, Harsh LN, Kathju S. Agroforestry in the arid zones of India. Agrofor Syst.1987, 5:69-88.

12. Singh D, Singh RK. Kair (Capparis decidua). a potential ethnobotanical weather predictor and livelihood security shrub of the arid zone of Rajasthan and Gujarat. Indian J. Tradit. Know. 2011, 10 (1):146-155.

13. Om Prakash. Food and Drinks in Ancient India. Munsi Ram Manohar Lal. Delhi. 1961, 340.

14. Kamal R. Economy of Plants in The Vedas. Common Wealth Publishers, New Delhi. 1988, 138.

15. Banerjee SC. Flora and Fauna in Sanskrit Literature. Naya Prokash, Calcutta, 1980, 192.

16. Sharma PV. Fruits and vegetables of ancient India. Chaukhamba Orientalia, Varanasi, Uttar Pradesh. India. 1979, 188.

17. http://www.efloras.org/florataxon.aspx?flora_id=5\&t axon_id=250063266

18. Kamel W, Abd El-Ghani M, El-Bous M. Taxonomic Study of Capparaceae from Egypt: Revisited .The African Journal of Plant Science and Biotechnology. 2009, 3 (1): 27-35

19. Sarawat KS. Archaeobotanical remains in ancient cultural and sociodyanmic of the Indian subcontinent.
Palaebotanist. 1992, 40:514-515.

20. Mehra KL. Bio diversity and subsistence changes in India: The Neolithic and Chalocolithic Age. Asian Agri-History. 1997, 1(2):105-126.

21. Arora RK, Nayyar ER. Wild relatives of Crop plants of India. National Bureau of Plant Genetic Resources (NBPGR), Kapoor Art Printing Press, New Delhi, India. 1984.

22. Agarwal V, Chavan BM. A study on composition and hypolipidaemic effect of dietary fibre from some plant foods. Plant Foods Hum Nutr. 1988, 38: 189-197.

23. Watt G. Dictionary of Economic Products of India. Vol. 5. Cosmo Publications, New Delhi, India. 1892, 676. (Reprint 1972.)

24. Mishra SN, Tomar PC, Lakra N. Medicinal and food value of Capparis - a harsh terrain plant. Indian J Traditional Knowledge. 2007, 6(1):230-238.

25. Sen P. Traditional Plant Use in Family Welfare. In. Patil DA edt. Herbal cures traditional Approach.Aavishkar Publishers, Distributors, Jaipur. India. 2008,1-41.

26. El Tahir BA, Gebauer Jens. Non-timber Forest Products: Opportunities and Constraints for Poverty Reduction in the Nuba Mountains, South Kordofan, Sudan. Conference on International Agricultural Research for Development. 2004.

27. Goodman SM, Hobbs JJ. The Ethnobotany of The Egyptian Eastern Desert: A comparison of common plant usage between two culturally distinct Bedouin groups. Journal of Ethno pharmacology. 1988, 23:7389.

28. Goyal M, Sharma SK. Traditional wisdom and value addition prospects of arid foods of desert region of North West India. Indian J. Trad. Know. 2009, 8(4): 581-585.

29. Rai S. Chemical examination of edible plants of Rajasthan desert with special reference to Capparadaceae. Curr Agric. 1987, 11:15-23.

30. Achaya KT. A Historical Dictionary of Indian Food. Oxford University Press, Delhi. 1998, 343.

31. Dhakad PK, Sharma PK, Kumar K. A Review on Ethnobiological \& Medicinal Potential of Capparaceae Family Plant: Capparis decidua. Advances in Pharmacology and Pharmacy. 2016, 4(3): 27-39.

32. van Valkenburg JLCH, Bunyapraphatsara N. (Editors) Plant Resources of South-East Asia No 12(2) Medicinal and poisonous plants 2, Backhuys Publishers, Leiden 2001.

33. Nadkarni KM. Indian Materia Medica. Part-I, 3rd Ed. Vegetable Kingdom. 1954, 265.

34. Khan A, Mehmood S, Khan RU, Khan SU. Ecological, Taxonomical and Ethenobotanical Study of Wild Fruit Producing Xerophytes of District Bannu. Journal of Medicinal Plants Studies. 2013, 1(4):112-120.

35. IBPGR. Forage and browse plants for arid and semi-arid Africa. International Bureau of Plant Genetic Resources, Rome.1984, 81

36. Meghwal PR, Tiwari JC. Kair (Capparis decidua (Forsek.) Edgew. - A multipurpose woody species for Arid Regions. Forests, Trees and Livilihoods.2002, 
12(4):313-319.

37. Lansky et al. Traditional Herbal Medicines for Modern Times. CRC Press, New York, 2013; 110.

38. Gull Tehseen, Mahmood Z, Anwar F, Sultana Bushra, Nouman W, Shahid S Ali, Iqbal MZ. Variation of Proximate Composition and Minerals within different Parts of Capparis decidua (Forssk.) Edgew. as a Function of harvesting seasons Pak. J. Bot.2015, 47(5): 1743-1748.

39. Younas M, Nouman W, Zubair M, Manzoor SA, Asraf I. Seed priming improves, emergence potential, growth behaviour, nutritional quality of Capparis decidua (Forsk.) Edgew. under drought stress. Pak J. Life Sciences.2016, 14(3): 135-143.

40. Holechek JL, Pieper RD, Herbel CH. Range management. Principles and Practices. (3rd Ed) Prentice Hall, Upper Saddle River, New Jersey, USA. 1998.

41. Mitre V. Wild Plants in Indian Folk Life-A Historical Prospective. In Jain SK. Edt. Contributions to Indian Ethnobotany. Scientific Publishers, Jodhpur. 1991, 39-59.

42. Odedra Nathabhai K. Ethnobotany of Maher Tribe in Porbandar District, Gujarat, India. PhDThesis, Saurashtra University. 2009, 459.

43. Jain RK. Fuel wood characteristics of medium tree and shrub species of India. Bioresour Technol .1994, 47(1):81-84.

44. Vaghela AM. Surface grasshopper control through pulverizing clods. Honey Bee 1993, 5(2):15

45. Jala ML. Combating Aphids in Fruits and Vegetables. Honey Bee. 2005.16(4): 45.

46. Dipti, Jaiswal ML. Karīra (Capparis decidua Edgew.) - An Important Medicinal Plant of Arid Zone Int J Ayu Pharm Chem. 2016 5(2):120-130.

47. Roy P, Gupta HN, Roy M. Susruta Samhita (A scientific Synopsis). INSA, New Delhi. 1993; 459.

48. Sensarma P. Plants in Indian Puranas. Naya Prokash, Calcutta, India. 1989,191.

49. Vaidya PG. Dravauna Shashtra, University Granthniman Board, Gujarat State. 1995, 454.

50. Sharma PV. Dravagunavijana. Vol. II. Vegetable drugs. Chaukhambha Bharati Academy. 2005, 530-531.

51. Shashtri GM. Bhavprakash . Part I. I ${ }^{\text {st }}$ Ed. Sastu Sahitya Vardhakkaryala. 1957, 368.

52. Sharma PV. Classical uses of Medicinal plants. Chaukhambha Vishwabharati. Varanasi Uttar Pradesh. India. 1996, 848.

53. Vaidyaratnam PS. Varrier's Indian Medical Plants: A Compendium of 500 species. Vol.I. Arya Vaidaya Shala. Kottakkal. 1994, 368.

54. Chunekar KC, Pandey GS. Bhavprakah Nighantu. Chaukhambha Bharati Academy, $8^{\text {th }}$ Edition. Gokulbhavan, Varanasi. 1999,546.

55. Saxena VK, Goutam Aparjita: Isolation and study of the flavone glycoside: Luteolin-7-o-D-Glucopyranoside from the seeds of Capparis decidua (Forsk). Int J. Chem Sci. 2008,6(1):7-10.

56. Khare CP: Indian medicinal plants. Springer India Pvt. Ltd. 2007, 117.
57. Chopra RN, Nayar SL, Chopra IC. Glossary of Indian Medicinal Plants. 7th reprint. National Institute of Science Communication and Information Resources, New Delhi. 2006, 49-50.

58. Kirtikar KR, Basu BD. Indian Medicinal Plants. vol. I, Second ed., M/S Bishen Singh Mahendra Pal, Delhi. 1933,197.

59. Sharma R. Medicinal Plants of India - An Encyclopedia, Daya Publishing house, New Delhi. 2003, 42-43.

60. 60.http://www.druginfosys.com/herbal/herb.aspx?cod e=337\&name $=$ capparis $\% 20$ decidua $\% 20$ linn. \&type $=1$

61. Kumar S, Parveen F, Goyal S, Chauhan A. Ethnobotany of Shrubs of Arid Rajasthan. In Narain P, Singh M, Khan MS, Kumar S. (Edts). Shrubs of Arid zone. Arid Agro-ecosystem Directorate Central Arid Zone Research Institute Jodhpur. 2005, 13-28.

62. Achal ji Maharaj. Sugham Chikitsa, Swami Achal Narayan, Jodhpur. 1961, 355

63. Marwat SK, Fazal-ur-Rehman, Usman Khalid, Khakwani AA, Ghulam Said, Anwar N, Sadiq M, Khan SJ. Medico-ethnobotanical studies of edible wild fruit plants species from the flora of north western Pakistan (D. I. Khan district). Journal of Medicinal Plants Research.2011, 5(16): 3679-3686.

64. Shekhawat D, Batra A. Household remedies of Keshvraipatan tehsil in Bundi district, Rajasthan. Indian Journal of Traditional Knowledge. 2006, 5(3): 362-367.

65. Meena KL, Yadav BL. Some ethnomedicinal plants of Southern Rajasthan. Ind. J. Trad. Know. 2010, 9(1): 169- 172.

66. Meena AK, Rao MM. Folk herbal medicines used by the Meena community in Rajasthan Asian Journal of Traditional Medicines. 2010, 5 (1):19-31.

67. Mohammed MS, Khalid HS, Osman WJ, Muddathir AK. A Review on Phytochemical Profile and Biological Activites of Three Anti-Inflammatory Plants used in Sudanese Folkloric Medicine. American Journal of Pharm Tech Research. 2014, 4(4):1-4.

68. Panghal Manju, Arya Vedpriya, Yadav S, Sunil Kumar, Yadav JP.Indigenous knowledge of medicinal plants used by Saperas community of Khetawas, Jhajjar District, Haryana, India. Journal of Ethnobiology and Ethnomedicine. 2010, 6:4

69. Patel SD, Ant HM. Ethnomedical value of some weeds of Patan District, Gujarat, India. The World J. of Engg. Applied Sciences. 2019, 5(2):1-11.

70. Joshi KI: Floristic, Phyto-sociological and ethnobotanical studies of Cambay Taluka, $\mathrm{PhD}$ Thesis, University of Bhavnagar. 1994, 383.

71. Atta-ur-Rahman M, Choudhary I, Bullo S. Medicinal Plants of Sindh. Indigenous Knowledge and Scientific Fact. Planning and Development Department Government of Sindh. 2013.171.

72. Boulos L. Medicinal Plants of North Africa. Reference Publications, Inc., 218 St. Clair River Drive, Box 344, Algonac, Michigan 48001. 1983, 286.

73. Elhassan Idm'hand, Msanda F, Cheri K. Ethnopharmacological Review of Medicinal Plants 
used to manage diabetes in Morocco. Clinical Phytoscience . 2020, 6:18.

74. Bebawi FF, Neugebohrn L. A Review of Plants of Northern Sudan with special reference to their Uses. Deutsche Gesellschaft für technische Zusammenarbeit (GTZ) GmbH, Postfach 5180, D-6236, 1991.

75. Khalid H, Abdalla WE, Abdelgadir H, Opatz T, Efferth T. Gems from traditional north-African medicine: medicinal and aromatic plants from Sudan.Nat. Prod. Bioprospect. 2012.

76. Khan FM. Ethno-veterinary medical usage of flora of greater Cholistan Desert (Pakistan). Pakistan Vet. J. 2009, 29(2): 75-80.

77. Al Yahya MA. Phytochemical studies of the plants used in traditional medicine of Saudi Arabia. Fitoterapia.1986, 57(3):179-182.

78. Atiqur RM, Mossa JS, Al-Said MS, Al-Yahya MA. Medicinal plant diversity in the flora of Saudi Arabia 1: Areport on seven plant families. Fitoterapia.2004, 75(2):149-161.

79. El Ghazali GEB, El-Tohami MS, El-Egami AAB. Medicinal plants of the Sudan. Part III. Medicinal plants of the White Nile provinces. National Center for Research, Khartoum, Sudan. 1994.

80. El Ghazali GEB, El-Tohami MS, El-Egami AB, Abdalla WS, Mohammed MG. Medicinal Plants of the Sudan. Part IV. Medicinal Plants of Northern Kordofan. Omdurman Islamic University Press, Khartoum, Sudan. 1997.

81. El Kamali HM, El Khalifa KF. Folk medicinal plants of riverside forests of the southern Blue Nile district, Sudan. Fitoterapia. 1999, 70: 493-497.

82. Kerharo J, Adam JG. La pharmacopée sénégalaise traditionnelle. Plantes Médicinales et toxiques. Editions Vigot Frères. Paris, 1974, 1011.

83. Thulin M. Capparis. Flora of Somalia. Angiospermae (Hydrocharitaceae, Pandanaceae), Vol. 1. Kew, London: Royal Botanic Gardens. 1993, 52-53.

84. Teklehaymanot T. An ethnobotanical survey of medicinal and edible plants of Yalo Woreda in Afar regional state, Ethiopia Journal of Ethnobiology and Ethnomedicine. 2017; 13:40.

85. Dubaria AG. Ulcer on Neck of Bullock Using Coal of Kerda'wood (Livestock). Honey Bee. 1991, 2(1):21.

86. Khatana LB. Charcoal repairs fractured Bones. Honey Bee.1997, 8(3): 13.

87. Rabari RM. Healing Maggot infested Wounds. Honey Bee. 2008; 19(3):19303.

88. Patel CB. Floral Primordia of Kerda. Honey Bee. 1991, 2(1):20.

89. Duhan A, Chauhan BM, Punia D. Nutritional value of some non-conventional plant foods of India. Plant Foods Hum.Nut. 1992, 42 (3), 193-200.

90. Dahot MU. Chemical evaluation of the nutritive value of flowers and fruits of Capparis decidua. J Chem Soc Pak 1993, 15:78-81.

91. Bala A, Goyal M. Pickles of arid fruits kair (Capparis decidua): an avenue of export. In $4^{\text {th }}$ Agricultural Congress on sustainable Agricultural Exports. Jaipur .1999, 3-4.

92. Goyal R, Grewal RB. The influence of teent
(Capparis decidua) on human plasma triglycerides, total lipids and phospholipids. Nutr. Health. 2003, 17 (1): 71-76.

93. Kumar S, Ali S, Singh G, Saxena SN, Sharma S, Mahala HR, Sharma TB, Sharma R. Association and variation among some important nutritional traits of ker (Capparis decidua). Annals Arid Zone. 2011, 50: 1-6.

94. Kumar S, Sharma R, Kumar V, Vyas GK, Rathore A. Combining molecular-marker and chemical analysis of Capparis decidua (Capparaceae) in the Thar Desert of Western Rajasthan (India). Rev. Biol. Trop. (Int. J. Trop. Biol. ISSN-0034-7744). 2013, 61 (1): 311-320.

95. Goyal Madhu, Rathore Reema, Dunkwal Vimla, Anju Bala. Nutritional Composition and Processing of Arid Fruit Ker (Capparis decidua) .Ind. J. Extn. Educ. \& R.D. 2014, 22 : 134-

96. Chauhan EM, Duhan A, Bhat CM. Nutritional value of ker (Capparis decidua) fruit. Journal Food Science Technology. 1986, 23(2):106-108.

97. Rathore Mala. Nutrient content of important fruit trees from arid zone of Rajasthan. Journal of Horticulture and Forestry. 2009, 1(7) L: 103-108.

98. Rai S: Oils and fats in arid plants with particular reference to Capparis decidua L. Trans. Indian Soc Des Technol. 1987, 12:99-105.

99. Rathee S, Rathee P, Rathee D, Rathee D, Kumar V. Phytochemical and pharmacological potential of kair (Capparis decidua). International Journal of Phytomedicine. 2010, 2(1):10-17.

100. Anonymous. Quality control methods for medicinal plant materials, revised, Geneva. 2005.

101. Johnson RK, Widerholm T, Rosenberg DM. Freshwater biomonitoring using individual organisms, populations, and species assemblages of benthic macroinvertebrates. In: Freshwater Biomonitoring and Benthic Macro- invertebrates. (Eds.): Rosenberg DM, Resh VH. Chapman and Hall, New York USA, 1993, 40-158.

102. Ahmad K, Ashraf M, Khan ZI, Valeem EE. Evaluation of macromineral concentrations of forages in relation to ruminants' requirements: a case study in Soone Valley, Punjab, Pakistan. Pak. J. Bot. 2008, 40: 295-299.

103. Gailer J, George GN, Pickering IJ, Madden S, Prince RC, Yu EY, Denton MB, Younis HS, Aposhian HV. Structural basis of the antagonism between inorganic mercury and selenium in mammals. Chemical Research and Toxicology. 2000, 13: 1135-1142.

104. Muhammad A, Dangoggo SM, Tsafe AI, Itodo AU, Atiku FA. Proximate, minerals and anti-nutritional factors of Gardenia aqualla (Gaudendutse) fruit pulp .Pakistan J. Nutr. 2011, 10: 577-581.

105. Tan JC. Burns DL, Jones HR: Severe ataxia, myelopathy and peripheral neuropathy due to acquired copper deficiency in a patient with history of gastrectomy. Journal of Parental Nutrition.2006, 30: 446-450.

106. Chaturvedi Yamini, Nagar Ranjana. An underutilized novel Xeric crop (Capparis decidua). In Thomas Sabu, Rajakumari Rajendran, George Anne, Kalarikkal Nandkumar. CRC Press. 2018, 452-468. 
107. Haq MZ, Cavar S, Qayum M, Imran I, Feo VD. Compositional studies: antioxidant and antidiabetic activities of Capparis decidua (Forsk.) Edgew. Int. J. Mol. Sci. 2011, 12:8846-8861.

108. Hu FB, Stampfer MJ, Manson JE, Rimm E, Colditz G A, Rosner BA, Hennekens CH, Willett WC. Dietary fat intake and the risk of coronary heart disease in women. N. Eng. J. Med. 1997, 337: 1491-1499

109. Nieves Jr C, Langkamp-Henken B. Arginine and immunity: a unique perspective. Biomed. Pharmacother. 2002, 56: 471-482.

110. Mahasneh AM. Screening of some indigenous Qatari medicinal plants for antimicrobial activity. Phytother. Res. 2002, 16: 751-753.

111. Upadhyay RK. Kareel plant: A natural source of medicines and nutrients. International Journal of Green Pharmacy. 2011, 5: 255-265.

112. Zaman Shahiq UZ, Akhtar N, Khan BA, Mahmood T, Rasul A, Mahmood A, Amir N, Ali Atif. Development of a sebum control cream from a local desert plant Capparis decidua. Journal of Medicinal Plants Research. 2012, 6(5): 744-748.

113. Brahmbhatt MR. Phytochemical screening of latex containing plants of North Gujarat region. Life Sciences Leaflets. 2012, 6: 29-31.

114. Rashid S, Lodhi F, Ahmad M, Usmanghani K. Preliminary cardiovascular activity evaluation of capparidisine, a spermidine alkaloid from Capparis decidua. Pak J Pharmacol. 1989, 6: 6- 16.

115. Ageel AM, Parmar NS, Mossa JS, Al-Yahya MA, Al-Said MS,Tariq M. Anti-inflammatory activity of some Saudi Arabian medicinal plants. Agents Actions. 1986, 17: 383-384. doi: 10.1007/BF01982656.

116. Ahmad VU, Ismail $\mathrm{N}$, Arif $\mathrm{S}$, Amber AR. Isocodonocarpine from Capparis decidua. Phytochemistry .1989, 28:2493-2495.

117. Dev SK, Shukla A, Choudhury PK, Singh GK. Analgesic and anti-nociceptive activity of hydroethanolic extract of Capparis decidua (Forssk.) Edgew. Asian Journal of Pharmacy and Pharmacology. 2015, 1(1):40-44.

118. Mohammed MS, Khalid HS, Muddathir AK, Tahir KEH, Osman B, Osman WJA, Basudan O. Effect of two sesquiterpene lactones from Capparis decidua (Forsk.) on arachidonic acid and adenosine diphosphate-induced platelets aggregation. J. Phytopharmacol. 2014, 3(3): 176-179.

119. Juneja TR, Gaind KN, Panesar A. Investigation on Capparis decidua edgew., study of isotgiocynate glucoside. Res Bull Punjab Univ Sci. 1970, 21: 519-521.

120. Gaind KN, Juneja TR, Bhandarkar PN: Volatile Principles from seeds of Capparis decidua. (Kinetics of in vitro antibacterial activity against Vibrio cholerae, Vibrio ogava, Vibrio inaba and Vibrio eltor). Ind J Pharm. 1972, 34:86-88.

121. Athanasiadis G, Moral P: Spatial principal component analysis points at global genetic structure in the Western Mediterranean. Journal of Human Genetics. 2013, 58 (11):762-765.
122. Rathee P, Rathee D, Rathee D, Rathee S: In-vitro cytotoxic activity of $\beta$-Sitosterol triacontenate isolated from Capparis decidua (Forsk.) Edgew. Asian Pacific Journal of Tropical Medicine. 2012, 5(3):225-230.

123. Rathee P, Rathee D, Rathee D, Rathee S. In vitro anticancer activity of stachydrine isolated from Capparis decidua on prostate cancer cell lines. Natural Product Research. 2012, 26(18):1737-1740.

124. Nazar S, Hussain MA, Khan A, Muhammad G, Tahir MN. Capparis decidua (Forsek.) Edgew. A comprehensive review of its traditional uses, phytochemistry, pharmacology and nutra pharmaceutical potential. Arabian Journal of Chemistry. 2020, 13: 1901-1916.

125. El Ghazali GEB: Medicinal Plants of Sudan Part I. Medicinal Plants of Erkawit, National Council for Research, Khartoum, 1986.

126. Anonymous. The Wealth of India. Raw Materials. CSIR, Delhi, India. 1950, 2:67.

127. Thoen D, Thiam A. Utilisations des plantes ligneuses et sub-ligneuses par les populations de la région sahélienne du lac de Guiers (Sénégal). Bull. Méd. Trad. et Pharm. 1990; 4(2):169-178.

128. Boury NJ.Végétaux utilisés dans la médecine africaine dans la région de Richard-Toll (Sénégal).dans: Adam, J., Les plantes utiles en Afrique occidentale. Notes Africaines. 1962, 93:1416.

129. Ahmad VU, Ismail N, Arif S, Amber AR. Two new $\mathrm{N}$-acetylated spermidine alkaloids from Capparis decidua. J Nat Prod. 1992, 55 (10):1509-1512.

130. Gaind KN, Juneja TR, Jain PC. Anthelmintic and Purgative Activity of Capparis decidua Edgew. Indian J Hosp Pharm. 1969, 2: 153-155. A

131. Purohit A, Vyas KB. Hypolipidaemic efficacy of Capparis decidua fruit and shoot extract in cholesterol-fed rabbits. Indian J Exp Biol. 2005, 43: 836-866.

132. Purohit A, Vyas KB. Antiatherosclerotic effect of Capparis decidua fruit extract in cholesterol-fed rabbits. Pharmaceutical Biol. 2006, 44: 172-177.

133. Dangi KS, Mishra SN. Antihyperglycemic, antioxidant and hypolipidemic effect of Capparis aphylla stem extract in streptozotocin induced diabetic rats. Biology and Medicine. 2010, 2(4): 35-44.

134. Ali SA, Al-Amin TH, Mohammad AH, Gameel AA. Hepatoprotective activity of Capparis decidua stem against Carbon tetrachloride-induced liver damage in rats. J. Pharmacol \& Toxicol. 2009, 4(4): 167.

135. Jhajharia KM, Agarwal SK, Srivastva B. Hepatoprotective activity of Capparis decidua on liver damage caused by thioacetamide in Wistar male rats. Int. J Toxicol. Pharmacol. Res. 2010, 2:92-94.

136. Gaind KN, Juneja TR, Jain PC. Investigations on Capparis decidua Edgew. Part II. Antibacterial and antifungal studies. Indian J Pharm. 1969, 31: 24-25 b

137. Gull Tehseen, Sultana Bushra, Bhatti I A, Jamil A. Antibacterial Potential of Capparis spinosa and Capparis decidua Extracts. International $\mathrm{J}$ Agric. Biol. 2015, 17: 723- 733.

138. Hundiwale JC, Sonawane RS, Patil RN, Hatapakki BC. Evaluation of Capparis decidua for anthelmintic 
and antimicrobial activities. Ind J Nat Prod. 2005, 20 (4): 10-13.

139. Upadhyay RK. Insecticidal Properties of Kareel Plant (Capparis decidua: Capparidaceae)- a Desert Shrub: A Review. World Journal of Zoology. 2013: 8(1): 75-93.

140. Verma PD, Dangar RD, Shah KN, Gandhi DM, Suhagia BN. Pharmacognostical Potential of Capparis decidua Edgew. Journal of Applied Pharmaceutical Science .2011, 01(10):06-11.

141. Mohammed MS, Khalid H S, MuddathirAK, Siddiqui NA, Ali M. A novel germacranolide sequiterpene lactone with anti-inflammatory effect from Capparis decidua (Forsk.). International J. Research in Pharmacy and Chemistry. 2012, 2(4):1073-1077.

142. Yadav P, Sarkar S, Bhatnagar D. Action of Capparis decidua against alloxan-induced oxidative stress and diabetes in rat tissues. Pharmacol Res. 1997, 36(3):221-228.

143. Chalia N. Effect of hypolipididamic activity in mice. J. Med. Plants Res. 2009, 3(6):481-484.

144. Goyal M, Nagori BP, Sasmal D. Sedative and anticonvulsant effects of an alcoholic extract of Capparis decidua. J. Nat.Med. 2009, 63 (4):375-379.

145. Eldeen IMS, Staden JV. Cyclooxygenase inhibition and antimycobacterial effects of extracts from Sudanese medicinal plants. S. Afr. J. Bot. 2008, 74 (2): 225-229.

146. Revathi P, Vani B, Sarathchandiran I, Kadalmani B, Shyam KP, Palnivel K. Reproductive toxicity of Capparis aphylla (Roth.) in male albino rats. Int $\mathbf{J}$ Pharm Biomed Res. 2010, 1(3):102-112.

147. Sarathchandiran I, Manavalan R, Akbarsha MA, Kadalmani B, Karar PK. Studies on spermatotoxic effect of ethanolic extract of Capparis aphylla (Roth). J Biol Sci. 2007, 7:544-548

148. Shah A, Gilani A. Blood Pressure Lowering Effect of the Extract of Aerial Parts of Capparis aphylla is mediated through Endothelium-Dependent and Independent Mechanisms. Clinical and Experimental Hypertension. 2011, 33(7): 470-477.

149. Gupta AK, Sharma M. Reviews on Indian medicinal plants, vol. 5 (Ca-Ce), Medicinal Plant Unit, ICMR, New Delhi, India. 2007, 389.

150. Sundararaj R, Rathore Mala, Tripathi YC. Aphicidal potential of Capparis decidua (Forsk) against the green peach aphid Mysus persicae (green) (Aphididae: Homoptera) on cabbage. Pestology. 1998, 22(11): 38-41.

151. Tripathi YC, Rathore Mala, Kumar H, Sundararaj R. Bioefficacy of Capparis decidua (Forsk) against Lipaphis erysimi (Kart) (Aphididae: Homoptera). Ann. Entomol. 1999, 17(2): 13-16.

152. Upadhyay RK, Jaiswal G, Ahmad S. Termiticidal effects of Capparis decidua on biochemical and enzymatic parameters of Odontotermes obesus (Isoptera: Termitidae). Acta Universitatis Sapientiae Agriculture and Environment. 2010, 2: 80-110.

153. Upadhyay RK, Rohatgi L, Chaubey MK, Jain SC. Ovipositional responses of the pulse beetle, Bruchus chinensis (Coleoptera: Bruchidae) to extracts and compounds of Capparis decidua. J Agric Food Chem.
2006, 54(26):9747-9751.

154. Murthy JM and P. Usha Rani. Biological activity of certain botanical extracts as larvicides against the yellow fever mosquitos, Aedes aegypti L. Journal of Bio-pesticides. 2009, 2(1): 72-76.

155. Shekhawat Jyotsna, Vyas N. Efficacy of Capparis decidua in control of Lymnea acuminata and their cercaria larvae at Balsamand lake Jodhpur. Journal of Applied and Natural Science. 2013, 5 (1): 137-138.

156. Tripathi YC, Singh Sushma, Anjum N, Srivastava KK. Antifungal Activity of Capparis decidua extracts against seed-borne pathogenic fungi. World J. Pharmacy and Pharmaceutical Sciences. 2015, 4(10):1500-1512.

157. Abdal Rahman Ayat AA, Tigani SE, Yagi Sakina. Biological activity of extracts of Capparis decidua $\mathrm{L}$. twigs. Journal of Medicinal Plants Research. 2016, 10(1):1-7.

158. Ahuja SC, Ahuja Uma, Sharma RD. Ayurvedic Characterization of Biopesticides. Asian Agri History. 2007, 11(2): 103-118.

159. Ahuja SC, Ahuja Uma, Ahuja Siddharth. Nirgundi (Vitex negundo) - Nature's Gift to Mankind. Asian Agri-History. 2015, 19(1): 5-32.

160. Ahuja SC, Ahuja Siddharth, Ahuja Uma. Nutraceautical wild Fruits of India-Lasora (Cordia)-History, Origin and Folklore. Sch. Acad J Biosci. 2020, 8(7): 187-209.

161. Arora P, Kumar S, Sharma MK, Mathur SP. Corrosion Inhibition of Aluminium by Capparis decidua in Acidic Media. E-Journal of Chemistry. http://www.e-journals.net 2007, 4(4):450-456.

162. Pratihar PS, Monika, Verma PS, Sharma Alka. Capparis decidua seeds: Potential green inhibitor to combat acid corrosion of Copper. Rayasan J. Chem. 2015, 8(4):411-421.

163. Pokharkarp RD, Funde PE, Joshi SS, Pingale SS. Synthesis and Characterization of Fatty Acid Methyl Ester by In-Situ Transesterification in Capparis decidua Seed. Leonardo Electronic Journal of Practices and Technologies.2008, 13(JulyDecember): 12-18.

164. Kumari Punita, Dixit SK, Dixit S, Prajapati R, Raza SK, Thakur LK. Green synthesis of silver nano particles by using Capparis decidua extract and its antibacterial studies. African Journal of Science and Research. 2015, (4)6:13-15.

165. Ahlawat Jyoti, Sehrawat Anita R. Biological synthesis of silver nano-particles using aqueous leaf extract of Capparis decidua (FORSK.) EDGEW: A better alternative. Journal of Pharmacy Research. 2015, 9(4): 244-249

166. Birajdar RM. Natural pH Indicator. Asian Journal of Pharma Analysis. 2020, 10(1):37-39.

167. Mahla HR, Rathore VS, Singh D, Singh JP: Capparis decidua (Forsk.) Edgew. an underutilized multipurpose shrub of hot arid region-distribution, diversity and utilization. Genet Resour Crop Evol.2013, 60:385-394.

168. Krishna H, Saroj PL, Maheshwari SK, Singh RS, Meena K, Chandra R, Parashar A. Underutilized fruits of arid \& semi-arid regions for nutritional and 
livelihood security. International Journal of Minor Fruits, Medicinal and Aromatic Plants. 2019, 5(2):1-14.

169. Samadia DK, SM Haldhar. Breeding strategies and scope of improvement in arid zone fruit crop-plants under abiotic stressed agro-climate: an analysis. Journal of Agriculture and Ecology. 2017, 4:1-13.

170. Bangarwa KS. Exploring Capparis decidua for livelihood and wasteland development.Asia-Pacific Agroforestry Newsletter. 2008, No. 322 (May): 3-5.

171. Pandey RP, Shetty BV. Rare and threatened plants of Rajasthan. In: Proc. Nat. Symp on Evaluation of Environment Species. Mishra SD, Sen DN, Ahmed J. (eds). Geobios Univ. Jodhpur, India. 1985, 238-241.

172. Vijay Namita, Arya Sarita, Arya ID. Rapid and Mass Propagation of the Economically Important Desert Plant Capparis decidua for its Afforestation Program. Journal of Arid Land Studies. 2014,24(1): 33-36.

173. Ahlawat J, Choudhary R, Sehrawat AR, Kaur S. Germplasm conservation via encapsulating in vitro generated shoot tips and nodal segment of Capparis decidua (FORSK.) EDGEW. and its regeneration. Rom Biotechnol Lett. 2019, 24(5): 783-788. DOI: 10.25083/rbl/24.5/783.788.

174. Jaspal DS. Tryst With Trees - Punjab's Sacred Heritage Thomson Press, New Delhi, 2010.

175. Sadhale Nalini. Upavana Vinoda (Woodland Garden for Enjoyment). Agri -History Bulletin No. 8. Asian Agri-History Foundation, Secunderabad, India. 2011, 64.

176. https://hindi.indiawaterportal.org/content/varaahamai haira-kaa-udakaaragala-bhaaga-2/book/7048178

177. Tiwari BN. Vrihat Hindi Lokoti Kosh. A Comprehensive Dictionary of Hindi Proverbs.
Shabdkar. Turkman Gate, Delhi, 1935: 1162.

178. Joseph E. Jatu Glossary- A Manual of the Language of Jats. Cosmo Publications.1910, 182

179. Rose HA. A Glossary of the Tribes and Castes of the Punjab and North-West Frontier Province Vol II. Printed by the Superintendent, Government printing, Lahore, Punjab.1911, 614.

180. Arya MS. Adhunik Jat Itihas. Agra. 1998, 228.

181. Satyarthi Devender. Bela phule Adhi Raat.Raj Hans Prakashan, Delhi. 1948,420.

182. Gupt KN. Bundeli Kahvat Kosh. Suchna Vibhag (Department of Information) UP. 1960, 366.

183. Sanskarta NR. Rajasthani Lok-Sahitya. Rajasthani Granthagar, Jodhpur. 2010,65.

184. https://www.speakingtree.in/blog/raskhan-ke-dohe-w ith-meaning-3

185. Sahal KL. Rajsthani Kahavaten-Ek Adhyayan. Bharati Sahitya Mandir, Delhi. 2010, 286.

186. Detha Vijay Dan: Rajasthani Hindi Kahavaten, A Dictionary of Rajasthani Proverbs. Rajsthani Grantha Gaar, Jaipur. 2001, Part 2:636; Part 3: 660.

187. Fellan SW. Hindostani Kahavat Kosh. National Book Trust, India. 1968, 373.

188. Singh RP. Ghagh Aur Bharari ki Kahavaten. Uttar Pradesh Hindi Sansthan. Lucknow. 2008, 204.

189. Sharma Palavi: James makonasche de kosh. Selected Agri lipiantan ate Samaj Sabhya car adhyan. PhD Thesis, Guru Nanak Dev University. 2016, 389.

190. Detha Vijay Dan. Rajasthani Hindi Kahavaten, A Dictionary of Rajsthani Proverbs. Rajsthani Grantha Gaar, Jaipur.2001, Part 3: 660.

191. Ghuman KS. Punjabi Akhan Kosh. Bhasha Vibhag (Language Department), Patiala, Punjab.1985, 364.

192. https://www.jatland.com/home/Karir. 